\title{
Memlükler Dönemi Hadis Literatürü Üzerine Bazı Değerlendirmeler*
}

\section{An Evaluation of The Hadith Literature During The Mamluk Period}

\section{Ferhat Gökçe'}

*Bu çalıșma, 19-20 Eylül 2019 tarihlerinde Istanbul Üniversitesi İslam Araştırmaları Merkezi tarafindan düzenlenen "Memlükler Döneminde İslami Ilimler Çalıştayı" başl|klı toplantıda sunduğumuz tebliğe dayanmaktadı.

'Sorumlu yazar/Corresponding author: Ferhat Gökçe (Doç. Dr.),

Ankara Yıldıım Beyazıt Üniversitesi İslami Ilimler Fakültesi, Ankara Türkiye

E-posta: ferhatgokce@hotmail.com

ORCID: 0000-0002-8181-1088

Başvuru/Submitted: 16.02.2021

Revizyon Talebi/Revision Requested:

23.08.2021

Son Revizyon/Last Revision Received: 01.09.2021

Kabul/Accepted: 01.09 .2021

Atıf/Citation: Gökçe, Ferhat. Memlükler Dönemi Hadis Literatürü Üzerine Bazı Değerlendirmeler. Islam Tetkikleri Dergisi-Journal of Islamic Review 11/2, (Eylül 2021): 439-475.

https://doi.org/10.26650/iuitd.2021.689915

\section{öz}

İslâmî ilimler tarihinin hicrî üçüncü asırdan sonra ikinci altın çağı, yaklaşık iki buçuk asır (648-923/1250-1517) hüküm süren Memlükler dönemine tekabül etmektedir. Memlükler'in İslâm dünyasında hâkim olduğu zaman dilimini kapsayan hicrî VII-X. asırlar özellikle hadis ilminin oldukça geliştiği, hadis literatürünün hemen her alanında çalışmaların telif edildiği bir dönem olmuştur. Memlükler dönemi, hadis âlimleri ve bu âlimler tarafından yazı ımıs eserler bakımından son derece zengindir. Çalışmamızda bu zenginliği oluşturan sebepler üzerinde durulmuş, İslâm tarihinin hicrî yedinci asırla onuncu asırlarına tekabül eden ve 250 yıldan fazla hüküm süren Memlüklerin ulaştı̆̆ı sınırlar içerisindeki hadis literatürü ana hatlarıyla ele alınmıştır. Bu makalede, Memlükler dönemi hadis âlimlerinin listesi çıkarımış ve bu âlimlerin telif ettikleri eserlerin hadis edebiyatının çeşitli türlerine dağılımından hareketle dönemin hadis tasnifinin genel karakteristiği üzerinde bir takım değerlendirmelerde bulunulmuştur. Hadis literatürünün yoğunlaştı̆̆ alanlar, dönemin hadis literatürünün temel hususiyetleri ve hadis ilminin alt dallarına ayrılarak incelenmesi, hadis ilmi açısından Memlükler döneminde telif edilen eserlerin önemi, bu eserlerin hadis ilminin gelişimine katkısı araştırmamızda ele alınan ve tartışılan konular olmuştur. Çalışmamızda Memlükler döneminin hadis literatürünü sıralamak gibi bir niyetimiz söz konusu değildir.

Bu makalede zaman zaman bir genellemeyle İslâm tarihinin hicrî VII-X. asırlarına tekabül eden, ilmî bakımdan "şerh ve hâşiye dönemi" olarak nitelendirilen, İslâm dünyasında Memlükler'in hâkim olduğu dönemin "gerileme dönemi" olarak nitelendirilmesinin hadis edebiyatı göz önünde bulundurularak hadis ilmi açısından kritiği yapılmıştır.

Anahtar Kelimeler: Memlükler, Hadis Literatürü, Hadis Şerhleri, Hadis Usulü Literatürü

\section{ABSTRACT}

The second golden age in the history of Islamic sciences after the third century $\mathrm{AH}$ is the period of the Mamluks, whose rule lasted about two and a half centuries (648-923/1250-1517). The 7th-10th centuries $\mathrm{AH}$, when the 


\begin{abstract}
Mamluks dominated the Islamic world, was a period in which the science of hadith was relatively advanced, and scholarly works were compiled in almost every field of hadith literature. The period of Mamluks is quite rich in terms of hadith scholars and the works written by hadith scholars. This study focuses on the reasons that brought about this wealth, and it provides an overview of the hadith literature within the geographical boundaries reached by the Mamluks, whose rule lasted over 250 years, corresponding to the seventh and tenth centuries of Islamic history. In this study, a list of the hadith scholars of the Mamluk period was drawn up, and the general characteristics of the hadith classification of the period were examined based on the distribution of the works that these scholars wrote in various types of hadith literature. This study investigated the main areas of focus in the hadith literature, basic features of the hadith literature of the period, the examination of the hadith literature by dividing it into subbranches of hadith science, the importance of the works written in the Mamluks period in terms of hadith science, and the contribution of these works to the development of this science. However, compiling a list of the hadith literature of the Mamluk period is beyond the scope of this study.

Commonly known as the period of "commentary (sharh) and annotation (hashiyah)", the 7th-10th centuries of the Islamic history, when the Mamluks dominated the Islamic world, is scientifically described as the "regression period" in terms of hadith literature. The present study critically evaluated this period through the lens of hadith science by taking into account the related hadith literature.
\end{abstract}

Keywords: The Mamluks, Hadith Literature, Hadith Commentaries, the Literature of Usul al-Hadith

\title{
EXTENDED ABSTRACT
}

In our study of $118(103+15)$ muhaddith of the Mamluk period, we identified 1,201 works. Some of the 1,201 works that we identified remain in the manuscript form and some of them are the works whose names have been mentioned and compared in the sources. These 1,201 works on the science of hadith during the Mamluk period are on the subjects of "hadith texts/compilations" (459), "hadith methodology" (85), "hadith rijal" (247), "hadith commentaries" (157), "hadith sciences" (35), and "other miscellaneous subjects" (218). It is understood that the studies of the period focused on hadith compilations, hadith requests, and hadith commentaries. It is demonstrated that the hadith literature of the Mamluk period concentrated on the fields of "hadith commentaries" (90), "hadith methodology" (85), "hadith compilations" (71), "single hadith commentaries" (67), "rijal" (60), "takhrij" (58), "ahkam" (48), "tabakat" (45)), "erbaun (forty hadiths)" (40), "turuku'l-hadith" (36), "vefeyat" (27), "zawaid" (26), "city history" (26), "mawduat" (19), and "atraf" (17). The study revealed that the most common type of hadith literature was hadith commentaries, with 157 works in the compilation focusing on them. Some 90 works on hadith sources and 67 works comprising one or more hadith commentaries were identified. Subsequently, it was observed that the "hadith method" with 85 works, "hadith compilations" with 71 works, and "forty hadith" with 60 works could be evaluated under hadith compilations. It is a definite sign of the period in which the Mamluks were assessed, with the period being identified as one of "compilation and commentary." Factually, a study conducted by this author on the sixth century Hijri showed that the century proceeding the Mamluk period was mainly a compilation period. As the next stage after compilations were commentaries, the number of commentaries gradually increased since the sixth century and peaked during the Mamluk period. The most remarkable 
and successful work found in the hadith literature of the Mamluk period is the commentaries. During this period, many commentaries and summaries were produced, especially on Bukhari and Muslim. As far as we determined in our study, 34 "commentary and summary" studies were conducted on Bukhari's al-Câmi, 15 on Muslim's al-Cami, 4 on al-Muvatta, 17 on Abu Davud's as-Sunan, 7 on Tirmidhi's as-Sunan, 6 on Begavi's Mesabihu's-sunna, and 1 on his Sarhu's-sunna and 1 on Ahmad b. Hanbal's al-Musnad during the Mamluk period.

If we consider the hadith literature in two parts as works based on a script and text, we can say that researches and studies on the text are predominant, although studies are conducted in the sciences related to the isnād in the Mamluk period. Conversely, the commentary activity, which has developed since the fourth century of the hijra, in other words, the explanation (tafsir), understanding, and interpretation of the hadiths included in the commentary, seems to be the most fundamental issue of the period.

Only the work of jurist and muhaddith al-Nawawi (d. 676/1277), whose full name was "el-Minhâc fi şerh-i Sahih-i Muslim b. Haccac," which is considered to be one of the most important and best of the Muslim commentaries, commentary on Bukhari's Sahih by Mogultay b. Kilic (d. 762/1360), a jurist, historian, linguist, and critic; the commentary of Kirmani (d. 786/1384), who is described as a jurist, methodologist, theologian, commentator, and linguist, the commentaries of Ibn Hajar (d. 852/1449), an expert on fiqh, history, and biography, and Aynî (d. 855/1451), historian, jurist, and scholar exceed 100 volumes in total. When these commentaries are examined, it is clear that they are mainly focused on "ilm dirayeti'l-hadith." Each of these works has taken its place among the rich encyclopedic hadith studies, reflecting that their authors are versatile scholars. The hadith commentaries written during the Mamluk period are sufficient to show how "text-oriented" hadithism became the center of attraction for the field of hadith. The first examples of many classification types that had not been seen in previous periods were written in the Mamluk period.

The foremost of these new classifications were the zawaids. Considering the intense studies on zawaid literature, some hadith historians described this period as the zawaid period. In fact, in the work named Hadith History of Izmirli Ismail Hakkl, which deals with the history of hadith in eight periods and is known as the first hadith history book in Turkey, the last two periods of the history of hadith were designated "the era of zawaid type works" and "the period after zawaid". In this period, numerous studies were conducted in the field of rijal and tabakat. We identified 60 works on hadith rijal, 84 works on mu'jamu'ş-suyuh, 45 on tabakat, and 27 on the field of history and vefayat. This indicates that hadith scholars were also interested in studies on the science of rijal, which was related to isnād, in this period. An essential part of the 40 works we identified comprises studies on the rijal of the main hadith sources, especially Bukhari and Muslim's al-Jami's. Rijal studies conducted during the Mamluk period show that "dirayetü'l-hadith" was performed alongside isnād studies, although the work was mainly textual in this period. 


\section{Giriş}

Hicrî yedinci asırda Eyyûbiler'den sonra İslâm dünyasının liderliğini Memlükler üstlendi. Mısır, Suriye ve Hicaz gibi önemli bölgelerde hüküm süren Memlükler, İslâm dünyasının doğuda Moğol, batıda ise Endülüs'ün haçl1 istilasına uğradığı bir dönemde kurulmuş, kuruluşunun hemen ardından hem Moğollara hem de haçlılara karşı zafer elde etmesiyle dönemin güvenlik içindeki yegâne İslâm ülkesi konumuna gelmişti. Bu dönemde istilâ altında olan İslâm ülkelerinden, Memlük Devleti'nin iki büyük merkezi Mısır ve Suriye'ye büyük bir göç hareketi başladı. Dönemin en istikrarlı İslâm ülkesi olan Memlük Devleti’ne sığınanlar arasında doğudan gelen âlimlerin yanı sıra Endülüs ve Kuzey Afrikalı mümtaz âlimler de yer almaktaydı. ${ }^{1} \mathrm{Bu}$ âlimlerin katkılarıyla Memlükler'in başşehri Kahire, Moğollar tarafından tahrip edilen İslâm dünyasın en önemli ilim ve kültür merkezi Bağdat'ın yerini almış oldu. ${ }^{2}$ Yaklaşık iki buçuk asır süren Memlükler'de Kahire ile birlikte Dımaşk sadece bu devletin değil, bütün İslâm dünyasının en önemli iki ilim merkezi olmuştur. Memlük idarecileri dönemin en geniş sınırlarına sahip olan İslâm devletini muhafaza ederken, Mısır ve Suriye merkez olmak üzere Memlük topraklarında yetişen âlimler de İslâm mirâsını korumuş, gelecek nesillere intikalini sağlamış, bu mirası yorumlamış ve zenginleştirmişlerdir.

Memlükler döneminde Kahire ve Dımaşk’ta mülteci hareketleri ve Memlük yöneticilerinin ilme ve ilim adamlarına karşı olumlu tutumları sayesinde elverişli kültürel ve ilmî bir ortam oluşturulmuştu. Ayrıca Abbâsî hilâfetinin Memlükler'in himayesinde Kahire'de yeniden tesis edilmesi de Memlük başkentini İslâm dünyasının en önemli siyâsî ve dinî merkezi haline getirmişti. Memlükler döneminde İslâmî ilimlerin her sahasında hummalı bir edebî faaliyet kendisini göstermiş, İslâmî ilimlerdeki gelişim bakımından İslâm tarihinin en parlak dönemlerinden birisi yaşanmıştır. ${ }^{3}$ Memlükler dönemindeki edebî faaliyetin en belirgin özellikleri şunlardir:

1. Yazılan eserler sayı bakımından oldukça zengindir.

2. Eserlerin başlıca özelliklerinden birisi, bugünün tabiriyle ansiklopedik denilecek türden, geniş hacimli ve muhtevalı olmasıdır.

3. Dönemin eserlerinin içerik bakımından zenginliği dikkat çekmektedir. Bu da dönemin âlimlerinin çok yönlülüğünü ortaya koyan bir husustur.

4. Geçmişte yapılan çalışmalar esas alınmıştır. Bu dönem şerh-hâşiye dönemi olarak kabul edilmektedir.

5. Hadis çalışmaları yaygınlaşmıştır.

6. Tasavvufî hareketler hızlanmıştır.

1 Memlükler dönemi âlimlerinden pek çoğunun Bağdat’ta, diğer doğu vilayetlerinde veya Endülüs şehirlerinde doğup büyümeleri daha sonra Mısır ve Suriye'ye gelmeleri bu hususu teyit etmektedir. İsmail Yiğit, Siyasi Dini Kültürel Sosyal İslâm Tarihi: Memlükler (İstanbul: Kayıhan Yayınları, 1991), 7/244.

2 İsmail Yiğit, “Ayni’yi Yetiştiren Memlükler Dönemi İlmi Hareketine Genel Bir Bakış", Marmara Üniversitesi İlahiyat Fakültesi Dergisi 11-12 (1993-94), 27-28.

3 İsmail Yiğit, "Memlükler", Türkiye Diyanet Vakfi İslâm Ansiklopedisi (Ankara: TDV Yayınları, 2004), 29/94; Fatih Yahya Ayaz, Memlükler (1250-1517) (İstanbul: İsam Yayınları, 2015), 137-140. 
7. Fıkıh alanında içtihat kapısı fiilen kapanmış, mezhep taassubu yaygınlaşmış ve dört mezhebin usulleri dışına çıkılamamıştır. ${ }^{4}$

Memlükler döneminde ilmî hareketin vasıfları hakkında bu ön bilgilerden sonra söz konusu dönemde hadis ilminin genel özellikleri hakkında bazı bilgiler vermek istiyoruz. Öncelikle belirtelim ki incelediğimiz dönem mütekaddimûn olarak isimlendirilen dönemden yaklaşık iki asır sonrasına tekabül etmektedir. ${ }^{5}$ Bir başka açıdan İslâm'ın doğuşu ile içerisinde bulunduğumuz dönemin tam ortalarına tekabül etmektedir. Bu anlamda Memlük devrini bir orta dönem olarak değerlendirebiliriz. Hadis tarihinin gelişimini "oluşum", "gelişim”, “açılım”, daralma" ve “yeni dönem-dönüşüm dönemi” şeklinde beş dönemde ele alan Mehmet Emin Özafşar’ın tasnifine göre Memlükler dönemi, açılım dönemine tekabül etmektedir. Açılım dönemi, rivâyet döneminin sona erdiği beşinci asırdan onuncu asra kadar geçen yaklaşık beş asırlık zaman dilimini kapsar. Bu dönem sistemli bir şekilde hadis eğitim ve öğretim merkezlerinin kurulduğu, hadis kaynaklarını açıklama çabalarının bir sonucu olarak dördüncü asırda başlayan şerh edebiyatının Kastallânı̂’ye (ö. 923/1517) kadar en seçkin örneklerinin verildiği bir zaman dilimidir. Bu zaman zarfında yaşanan siyâsî ve sosyal çeşitlilik, Haçlı seferleri, Moğol istilası gibi yoğun nüfus hareketlenmelerine sebep olan büyük olaylar ve bunların yol açtığı fikir hareketlenmeleri görülmüştür. Memlükler döneminde, âdeta Moğolların yağma ve tahribine inat, hummalı bir yazın faaliyeti dikkat çekmektedir. ${ }^{6}$

Memlükler döneminde İslâmî literatür sayı bakımından oldukça zengin olmakla takdire şayan görülürken, nitelik bakımından ise büyük çoğunluğu itibariyle şerh ve haşiyelerden oluşmasından dolayı bu literatürün orijinaliteden uzak olduğu yönünde görüşler de ortaya atılmıştır. ${ }^{7}$ Ignaz Goldziher (1850-1921), Memlükler döneminde hadis âlimlerinin bütün mesâilerini geçmiş dönemde yapılan eserlere harcadıklarını, bu eserlere zevâid, şerh ve hâşiyeler yazdıklarını belirterek tüm bunları çöküşün şaşmaz belirtileri olarak değerlendirmiştir. Goldziher'e göre bu dönemdeki bol ve yaygın literal üretim sadece çok az sayıda özgün ve yaratıcı çalışma ile övünebilmiştir. ${ }^{8}$ Andre Miquel ise İslâm medeniyetinin Memlükler safhasından bahsedilmesi gerektiğini, Memlük dönemi edebiyatı derleme olsa da, bu dönemde yetişen âlimlerin zekâ, tecrübe ve büyük devlet olma özelliklerini katarak kalıcı büyük eserler verdiğini belirtmiştir. ${ }^{9}$

Memlükler döneminde İslâm âlimlerinin geçmişte yapılan çalışmalara yoğunlaşmalarının birçok sebebi üzerinde durulabilir. ${ }^{10}$ Memlük Devleti'nin hâkim olduğu topraklar, dönemin

4 Mehmet Görmez, Sünnet ve Hadisin Anlaşılması ve Yorumlanmasında Metodoloji Sorunu (Ankara: TDV Yayınları, 1997), 77.

5 Murteza Bedir, "Mütekaddimîn ve Müteahhirîn", Türkiye Diyanet Vakfi İslâm Ansiklopedisi (Ankara: TDV Yayınları, 2004), 32/186-188.

6 Mehmet Emin Özafșar, Hadis ve Kültür Yazıları (Ankara: Kitabiyat Yayınları, 2005), 34.

7 Carl Brockelmann, İslâm Milletleri ve Devletleri Tarihi, çev. Neşet Çağatay (Ankara: Ankara Üniversitesi İlahiyat Fakültesi Yayınları, 1964), 222-223.

8 Ignaz Goldziher, Klasik Arap Literatürü çev. Azmi Yüksel - Rahmi Er (Ankara: İmaj Yayınc1lık, 1993), 156.

9 Andre Miquel, İslâm ve Medeniyeti: Doğuştan Günümüze, çev. Ahmet Fidan - Hasan Menteş (Ankara: Birleşik Dă̆ııım Kitabevi, 1991), 200.

10 Kadiruddin Ahmed, İslâm Dinamizmi ve Entelektüel Atalet, çev. Ertuğrul Aytekin (İstanbul: İlke Yayınları, 1992), 38. 
en çalkantılı bölgelerinden birisiydi. Öte yandan Memlük tarihinin tüm dönemlerinde iç karışıklıklar, istikrarsızlıklar da hüküm sürmüştür. Bunlara rağmen Memlükler tüm kurumlarıyla bir medeniyet olgunluğuna erişmiş bir hânedân olarak tarihe geçmişlerdir. Bunun yanı sıra telif edilen ürünlerin geçmiş dönemlerin eserlerine bağlı olmasıyla, bunların orijinalliğinin birbirinden ayırt edilmesi gerekir. Şunu belirtmemiz gerekir ki, Memlükler dönemi genelde İslâmî ilimler, özelde hadis ilmi açısından bir duraklama ya da gerileme değil, ancak geçmiş dönemlerin temel alındığı bir yorumlama, açılım ve zenginleştirme dönemidir. Bu yüzden yukarıda yer verdiğimiz Goldziher'in görüşlerine katılmadığımızı burada hemen belirtmek isteriz. Elbette bu dönemde telif edilen eserler hicrî üçüncü asır hadis literatürüyle mukayese edilemez. Ancak bu dönemin çok az özgün çalışma ile övündüğü iddiası ise gerçeği yansıtmamaktadır. Çünkü söz konusu dönemde yazılan birçok eserin âdeta birer klasik haline gelmesi ve halen kullanımda olması, pek çok ihtiyacı karşılamaya devam etmesi, en azından hadis ilminin âlimleri ve eserleriyle bu çalışmada detaylarına yer vereceğimiz ulaştı̆̆ 1 seviye ve hadisin müesses konumu, "gerileme" iddialarını nakzetmektedir. Öte yandan şerh-haşiye dönemi olması hasebiyle, şerh faaliyetinin ya da şerhlerin sadece geçmişi tekrar etmek olmadığını, oldukça zor ve uzun mesaiyi gerektiren birer ilim-kültür hazineleri olduğunu belirtmek gerekir.

Memlükler dönemindeki ilmî hareketin ve hadis ilminin genel vasıfları hakkında bu özet bilgilerden sonra çalışmamızın asıl konusu olan Memlükler döneminde hadis edebiyatına geçmek istiyoruz.

Hadis tarihinin oluşum ve gelişimini kapsayan ilk dört asrı hıfz, kitâbet, tedvin ve tasnif dönemlerini içerisine almış, hicrî beşinci asrın başlarına kadar hadis kitaplarının tasnifi devam etmiştir. Bu dönemlerde hadis ilminde daha ağırlıklı "rivâyetü'l-hadîs" ilminin kapsamına giren çalışmalar yapılmıştır. Hicrî beşinci asrın sonlarından itibaren hadis ilmi, hadis metinleri üzerindeki çalışmalar yeni bir renge bürünmüştür. Hadis metinleri zabta geçirilip çeşitli tasniflerle kitaplardaki yerini almıştır. Artık kitap dışında bir metin pek bırakılmamıştır. $\mathrm{Bu}$ müddet zarfında kitaplarda senetleriyle birlikte yer almamış bir metin, şayet sonraki asırlarda "hadis" olarak ortaya çıkmışsa, bunun "hadis" olarak kabul edilmesi şüpheyle karşılanmıştır." Ali Yardım, hicrî beşinci asrın sonlarından itibaren hadis edebiyatının gelişimini, bizim esas aldığımız tasnifte "açılım” dönemine tekabül eden "şerh ve derlemecilik devri” olarak nitelendirdiği dönem öncesini şu sözleriyle özetlemektedir:

"Hicrî beşinci asır sonlarına doğru ise yeni bir çalışma dönemine geçilmiştir. Artık eski metotla yapılacak yeni bir iş kalmamış, bütün sistem ve gelenekleriyle bir devir kapanmıştır. Ne var ki, bir devrin kapanması demek, hiçbir şekilde o devrin yıkılması demek değildir. Öte yandan bir devrin kapanması demek hayatın durması demek de değildir. Nitekim önceki devir vazifesini eksiksiz yapmış, fonksiyonunu şerefle icrâ etmiş ve haleflerine çok zengin bir miras bırakarak nöbeti başkalarına devretmiştir." 12

11 Ali Yardım, Hadis I-II (İstanbul: Damla Yayınları, 2012), 2/105.

12 Yardım, Hadis I-II, 2/105. 
Bu nöbetin teslim alındığg Memlükler öncesini diğer bir ifadeyle hicrî altıncı asrı hadis ilminde literatürü temel alacak olursak "derlemecilik dönemi"13 olarak nitelendirebiliriz. Hicrî altıncı asırla başlayıp ve derlemecilik ya da "nakil dönemi" olarak adlandırılan dönemlerin en temel özelliği rivâyet usulüyle telif edilen temel hadis kaynaklarının kitap halinde nakli ve onlar üzerine yapılan farklı çalışmalar olmuştur. ${ }^{14}$ Gerek derlemecilik gerekse nakil dönemi olarak isimlendirilen dönemler bizim esas alığımız hadis tarihi dönemlendirmesinde Memlükler'in hemen öncesini ve Memlükler'in hüküm sürdüğü dönemleri içerisine alan açılım dönemine tekabül etmektedir. Bu asırda telif edilen derlemelerin en temel kaynağ 1 "Sahîhayn" ve "Kütüb-i Sitte"dir. Altıncı asırda "Sahîhayn" kavramı oturmuş ve yerleşmiş olmakla birlikte "Kütüb-i Sitte" ıstılahının hangi hadis kaynaklarını kapsadığı konusunda bir ittifak yoktur. Bununla birlikte hicrî altıncı asır bu kavramın ortaya çıktığı dönem olması bakımından önemlidir. "Kütüb-i Sitte” kavramının yerleşmesine sebep olan temel faktörlerden birisinin hadis derlemeciliği olduğunu söyleyebiliriz. Çünkü hadis eserlerinde derleme yapan hadis âlimleri, derlemelerinde esas aldıkları kitaplar, ya da Kütüb-i Sitte üzerine telif ettikleri eserler için bu ismi kullanmışlardır. ${ }^{15}$ Çalışmamızda inceleyeceğimiz Memlükler döneminde "Kütüb-i Sitte" 1stılahı konusunda farklı görüşler ileri sürülmüştür. Âlâî (ö. 761/1359) ve İbn Hacer el-Askalânî (ö. 852/1449) gibi âlimlere göre İbn Mâce’nin (ö. 273/887) es-Sünen'i yerine Dârîmî'nin (ö. 255/869) es-Sünen'i, Kütüb-i Sitte'nin altınc1 eseri olmaya daha layıktır. ${ }^{16}$

Memlükler hâkimiyeti altındaki İslâm dünyasında hadis edebiyatının değerlendirilmesinde mukaddime bâbında göz önünde bulundurulması gereken önemli hususlardan birisi de hadis kitaplarının telifinde hicrî altıncı asırdan itibaren senetlerin bırakılması olmuştur. Ancak bu asırda bütünüyle senetlerin bırakıldığı da söylenemez. Senetli ve senetsiz hadis rivâyeti bir arada yürütülmüştür. Bir hadis eserinde hadislerinin senetlerini ilk defa terk eden Begavî (ö. 516/1122) Mesâbîhu's-sünne'sinde ${ }^{17}$ hadislerin isnâdlarını terk ederken, Şerhu's-sünne'sinde hadisleri senetli olarak rivâyet etmiştir. Senetli rivâyet aktarımı bu asırda hadis usulüne dair eserlerde de terk edilmiştir. Bunun ilk örneğini Kâdî Iyâz (ö. 544/1149) vermiştir. Hadis usulü literatürünün tarihi gelişimi bakımından bu da önem arz etmektedir. Memlükler döneminde ise senetli hadis tasnifi artık bütünüyle son bulmuş, hicrî sekizinci asırda ortaya çıkan rivâyetü’lhadîs ilminin kapsamında değerlendirebileceğimiz "zevâid" türü ve diğer türlerdeki tüm eserlerde hadisler sadece sahâbî râvîleriyle rivâyet edilmiştir. Bu dönemde tek tek rivâyet hakkı alınan hadislerin senetleriyle nakli esasına dayanan tasnifler sona ermiş, senetleriyle kitapların nakli usulü benimsenmiştir.

13 Mehmet Sait Toprak, Hadiste Derlemecilik Devrinin Başlaması ve Ûş̂̀'nin Nisâbü'l-Ahbâr'ı (İzmir: Dokuz Eylül Üniversitesi, Sosyal Bililer Enstitüsü, Doktora Tezi, 2005), 2-3.

14 Ahmet Yücel, Hadis Tarihi (İstanbul: Marmara Üniversitesi İlahiyat Fakültesi Vakfı Yayınları, 2014 ), 18.

15 Muhammed b. Tâhir el-Makdisî, Şurûtu'l-Eimmeti's-Sitte, (Beyrut: Dâru'l-Kutubi'l-İlmiyye, 1984).

16 M. Yaşar Kandemir, "Kütüb-i Sitte”, Türkiye Diyanet Vakfi İslâm Ansiklopedisi (Ankara: TDV Yayınları, 2003), $27 / 6$.

17 İbrahim Hatiboğlu, "Mesâbîhu's-Sünne”, Türkiye Diyanet Vakfi İslâm Ansiklopedisi (Ankara: TDV Yayınlar1, 2004), 29/258. 
Üzerinde durulması gereken diğer bir husus Memlükler öncesi şerh faaliyetleri ile ilgilidir. Hicrî dördüncü asırda el-Hakîm et-Tirmizî (ö. 320/932) ve el-Hattâbî (ö. 388/998) ile başlayan ${ }^{18}$ hadis şerhleri sonraları artarak devam etmiş ve hadis şerhleri her dönemde kaleme alınmıştır. Hicrî altıncı asırda da bir takım hadis şerhleri yazılmıştır. Ancak bu asrın en belirgin yönü henüz "hadis şerhleri” değildir. Yukarıda da belirttiğimiz gibi altıncı asırda "derleme"lere ağırlık verilmiştir. Hadis tarihinde "şerh dönemi”" olarak anılabilecek dönem hemen hemen Memlükler'in hüküm sürdüğü asırlara tekabül etmektedir. Memlükler zamanında telif edilen hadis şerhleri önceki dönemlere göre hem çok daha fazladır hem de daha nitelikli bir hâl almıştır. Hicrî VI-IX. asırlarda telif edilen hadis şerhleri, IV.-VI. asırlarda telif edilen hadis şerhlerinden çok daha zengin, daha fazla mesai harcanmış mahsüller olarak karşımıza çıkmaktadır. ${ }^{19}$

Memlükler öncesi hadis usulüne de bir göz atmak yerinde olacaktır. Memlükler'in kuruluşundan altı yıl önce vefat eden İbnü’s-Salâh eş-Şehrezûrî’nin (ö. 643/1245) hadis usulüne dair kaleme aldığı tam adı Ma 'rifetü envâ'i 'ilmi'l-hadîs olan ve Ulûmü'l-hadîs ismiyle de bilinen çalışması kendisinden sonraki tüm hadis usulü eserlerini etkilemiştir. İbnü's-Salâh, bu önemli eserini Eşrefiyye Dârülhâdîs’inde hocalığa başladığg 630/1233 yılından itibaren yazmaya başlamış, yazdığı kısımları öğrencilerine imlâ ettirmek suretiyle 634/1237'de tamamlamıştır. ${ }^{20}$ Hadis usulünün mütekaddimûn eserleri arasında gösterilen Râmhürmüzî’nin (ö. 360/971) elMuhaddisü'l-fâsıl' 1, Hâkim en-Nîsâbûrî'nin (ö. 405/1014) Ma 'rifetü 'ulûmi'l-hadîs'i ve Hatîb el-Bağdâdî’nin (ö. 463/1071) el-Kifâye ve el-Câmi ' li-ahlâkı'r-râvî ve âdâbi's-sâmi 'isimli eserlerinden önemli oranda istifade etmiştir. İbnü’s-Salâh, en fazla Hatîb el-Bağdâdî’ye referansta bulunmuş, Hâkim en-Nîsâbûrî'nin elli iki bölüm halinde ele aldığı hadis konularını (ilimlerini) altmış beşe çıkarmıştır. ${ }^{21}$ Mukaddimetü İbni 's-Salâh yazıldığı dönemde hadis usulünün ihyâsı olarak kabul edilmiştir. ${ }^{22}$ Nitekim eser öncekilerden farklı olarak özgün bir tasnife sahiptir. Konularla ilgili hassas bir bölümleme yapılmış, görüşler titizlikle seçilerek karşılaştırmaları yapılmıştır. Terimler dikkatli biçimde tanımlanmış, örneklendirmeler yapılmış, değişik kanaatler

18 Muvatta üzerine yazılan bazı çalışmaların ilk şerhlerden olabileceği kanaati de dile getirilmektedir. Muvatta şerhlerinin bilinen ilk örneklerinin Mâlik b. Enes'in talebelerinden Abdullah b. Vehb (ö. 197/813) ve Abdullah b. Nâfi' es-Sâiğ'e (ö. 206/822) ait olduğu ifade edilmektedir. İbn Vehb'in Tefsîru Garîbi 'l-Muvatta'1 ile İbnü'sSâiğ'in Tefsîru'l-Muvatta'ı Muvatta'nın daha ilk muhataplarının elinde şerhedildiğini göstermeleri açısından önemli eserler olarak değerlendirilmiştir. Bk. Halit Özkan, "Muvatta Üzerine Yazılmış Şerhler”, Hadis Şerh Literatürü, ed. Mustafa Macit Karagözoğlu (İstanbul: İFAV, 2020), 57-58. Günümüze ulaşmayan ve içerikleri hakkında bilgi sahibi olamadığımız söz konusu eserlerin isminde "tefsir" kelimesinin geçmesinin ötesinde başka delillere ihtiyaç olduğunu burada belirtmemiz gerekir. Dolayısıyla söz konusu eserlerin Muvatta üzerine yapılan ilk çalışmalar olduğu söylenebilirse de ilk şerhler oldukları iddia edilemez. Tefsir kelimesinden hareketle senet ya da metne dair hususların açıklandığı (tefsir) edildiği izlenimi alınsa da bunun şerhe ne kadar tekabül ettiği meselesi hakkında görüş belirtebilmek için belirttiğimiz gibi başka delillere ihtiyaç duymaktayız.

19 Nitekim İbn Hacer el-Askalânî, Buhârî şerhi Fethu'l-bârî̀yi 23 senede, Bedruddîn el-Aynî, Umdetü’l-kârî'yi 25 senede tamamlamıştır. M. Yaşar Kandemir, "el-Câmiu's-Sahîh”, Türkiye Diyanet Vakfi İslâm Ansiklopedisi (İstanbul: TDV Yayınları, 1993), 7/119; Talat Sakallı, Aynî ve Hadis Yorum/Şerh Yöntemi (Ankara: Nobel Akademik Yayıncılık, 2013), 67-68.

20 M. Yaşar Kandemir, “Mukaddimetü İbni’s-Salâh”, Türkiye Diyanet Vakfi İslâm Ansiklopedisi, (İstanbul: TDV Yayınları, 2000), 31/121-122.

21 Takıyyüddin İbnü's-Salâh, Mukaddimetu İbni's-Salâh, thk. Nureddin Itr (Dımaşk: Dârü'l-fikr, 1986), 7-11.

22 M. Yaşar Kandemir, “Mukaddimetü İbni's-Salâh”, 31/121-122. 
tartışılmıştır. Bu özellikleri sebebiyle kendisinden sonraki hadis usulü çalışmalarının belirleyicisi konumunda olmuştur. ${ }^{23}$ Eser üzerine 40'tan fazla çalışma yapılmıştır. ${ }^{24}$ Memlükler döneminde telif edilen hadis usulü çalışmalarının neredeyse tamamı bu eseri temel alarak hazırlanmıştır.

Yaklaşık iki buçuk asırlık hadis tarihinin en çok ürün verilen dönemlerinden birisi olan Memlükler dönemi, hadis literatürü müstakil araştırmalara konu olacak mâhiyettedir. Biz konuyu iki bölümde inceleyeceğiz. Öncelikle telifleriyle hadis literatürünü şekillendiren hadis âlimleri ile hadis ilmine dair önemli eser veren dönemin âlimlerini tespit etmeye çalışacağız. Tespit ettiğimiz liste üzerinden dönemin İslâm coğrafyasındaki hadis faaliyetlerini gözden geçirmeye çalışacağız. Bu bölüme bağlı olarak teşekkül edecek ikinci bölümde ise söz konusu âlimlerin hadis ve hadis ilimlerine dair eserlerinin hadis literatürünün türlerine göre dağılımını belirleyerek ortaya çıkan tablo üzerinden bazı değerlendirmelerde bulunacağız.

Memlükler dönemi hadis literatürünün tespitinde, Türkiye Diyanet Vakfi Islâm Ansiklopedisi Memlük dönemi âlimlerinin biyografilerinden, Kettân̂̂'nin er-Risâletü'l-müstatrafe 'si ${ }^{25}$ ve Mücteba Uğur'un Hadis Illimleri Edebiyatı ${ }^{26}$ isimli eserinden ve Mahmut Yeşil'in Hadis Bibliyografyası ve Gelişimi ${ }^{27}$ isimli yüksek lisans tezinden istifade edilecektir. ${ }^{28}$ Memlükler dönemi tabakât ve biyografi kaynaklarının zenginliği ile öne çıkmaktadır. Bu yüzden Memlükler dönemi hadis literatürüne dair yapılacak kapsamlı bir çalışmada doğrudan bu literatürden azami ölçüde istifade edilmesi gerekmektedir. Bunun için yeterli ve gerekli bir zaman dilimine ve kapsamlı araştırmalara ihtiyaç duyulacağı kaçınılmazdır. Bu yüzden şimdilik buna hazırlık mahiyetindeki bu çalışmamızda mevcut birikimden istifade edilmiştir. Dolayısıyla Memlükler dönemi hadis âlimlerinin ve hadis literatürünün tamamını tespit etme gibi bir gayemizin olmadığını, başta da belirttiğimiz üzere dönemin en çok eser veren muhaddislerinden tespit edilenler ile en meşhûr âlimleri üzerinden değerlendirmelerde bulunacağımızı yenilememiz gerekmektedir.

Çalışmamızın ilerleyen bölümlerinde Memlükler dönemi hadis literatürünü şekillendiren faktörler üzerinde durulacak, örneklerini ilk defa Memlük hadis âlimlerinin verdiği hadis literatürü ve bu literatürü ortaya çıkaran ve genel olarak Memlükler dönemi hadis literatürünü

23 Mehmet Emin Özafşar, "Hadis İlminde Alan Evrilmesi” İslâmiyât 6/4 (2003), 115.

24 Ali Arslan, "Mukaddimetu İbni’s-Salah İsimli Eser Üzerine Yapılan Çalışmalar", İnsan ve Toplum Bilimleri Dergisi 6/5 (2017), 2460-2474.

25 Muhammed b. Ca'fer el-Kettânî, er-Risâletü'l-müstatrafe li beyâni meşhûri kütübi s-sünneti'l-müşserrefe, thk. Muhammed el-Muntasır b. Muhammed ez-Zemzemî b. Muhammed b. Ca'fer el-Kettânî (Dârü'l-Beşâiri'lİslâmiyye, 2000).

26 Mücteba Uğur, Hadis Illimleri Edebiyatı (Ankara: TDV Yayınları, 1996).

27 Mahmut Yeşil, Hadis Bibliyografyası ve Gelişimi (H. 700-1100/M. 1300-1688) (Konya: Selçuk Üniversitesi Sosyal Bilimler Enstitüsü, Yüksek Lisans Tezi, 1989).

28 Halit Özkan Memlüklerlerin son 125 y1lına tekabül eden dönemi Kahire özelinde ele almış, döneme dair seçme bir literatür denemesinde bulunmuştur. Halit Özkan, Memlüklerin Son Asrında Hadis (İstanbul: Klasik Yayınları, 2012), 202-221. Memlüklerin ilk dönemleri ise Nagihan Emiroğlu tarafından hazırlanan bir doktora tezinde ele alınmıştır. Bu çalışmanın ikinci bölümü "Hadis Hafızı olan Meşhur Âlimler ve Hadis İlmi İle İlgili Eserler" ismini taşımaktadır. Bölümde Memlükler döneminin hicrî VII-VIII. asırları hadis literatürü açısından genel hatlarıyla ele alınmıştır. Nagihan Emiroğlu, Türk (Bahri) Memlükler Döneminde Hadis İlmi (Adana: Çukurova Üniversitesi Sosyal Bilimler Enstitüsü, 2019), 111-247. 
şekillendiren sebepler tespit edilmeye çalışılacaktır. Memlükler döneminin en ayırıcı vasfı olan şerhler literatür bakımından değerlendirilecek, yine bu dönemdeki ricâl ve tabakât literatürü ile temel hadis kaynakları üzerine yapılan çalışmaların mâhiyeti ve İbnü's-Salâh sonrasına tekabül eden hadis usulü literatürünün durumu gibi konular üzerinde birtakım tespit ve değerlendirmelerde bulunulacaktır.

Memlükler dönemi hadis edebiyatına giriş mahiyetindeki bu mukaddimeden sonra dönemin hadis edebiyatını şekillendiren hadis âlimleri üzerinde durmak istiyoruz.

\section{Memlükler Döneminde Hadis Literatürünü Şekillendiren Âlimler:}

Memlükler döneminde çok sayıda muhaddis yetişmiştir. Memlük târihçisi ve muhaddis Nuaymî'nin (ö. 927/1521) ed-Dâris fî târîhi 'l-medâris isimli eserinde sadece Dımaşk'ta 396 muhaddisin ismini tespit etmiş olması bu konuda bizlere bir fikir vermektedir. ${ }^{29}$ İlmî ve kültürel hayatın çok daha canlı olduğu Kâhire'de bu rakamdan daha fazla muhaddisin yetiştiği tahmin edilebilmektedir. Bizim buradaki amacımız Memlükler döneminde yetişen tüm muhaddisleri tespit etmek değildir. Bu yüzden biz burada hadis ilminde eser bırakan, hadisçiliği ile şöhret bulan ve sonraki dönemlere etkisi olan yani "hadis edebiyatını şekillendiren" hadis âlimleri üzerinde durmak istiyoruz.

Memlükler dönemi hadis âlimlerinin büyük çoğunluğu Kahire ve Dımaşklı âlimlerden oluşmaktadır. Bu iki şehir aynı zamanda dönemin en önemli ilim merkezleridir. Bu iki şehrin dışında Memlükler'in sınırları içerisinde bulunan İskenderiye, Dimyat, Haleb, Harran, Hama, Mekke, Medine ve Kudüs gibi şehirlerde doğan ya da bu şehirlerde yetişen hadis âlimleri de bulunmaktadır. Memlük Devleti'nin sınırları içerisindeki ilim merkezleri harita ${ }^{30}$ üzerinde şu şekildedir:

29 Abdulkâdir b. Muhammed en-Nuaymî ed-Dımaşkî, ed-Dâris fî târîhi'l-medâris (Lübnan: Dârü'l-kütübi'l-ilmiyye, 1990).

30 Harita, Türkiye Diyanet Vakfı İslâm Ansiklopedisinden alınmıştır. Bk. İsmail Yiğit,"Memlükler”, Türkiye Diyanet Vakfi İslâm Ansiklopedisi (Erişim 03.08.2021). 


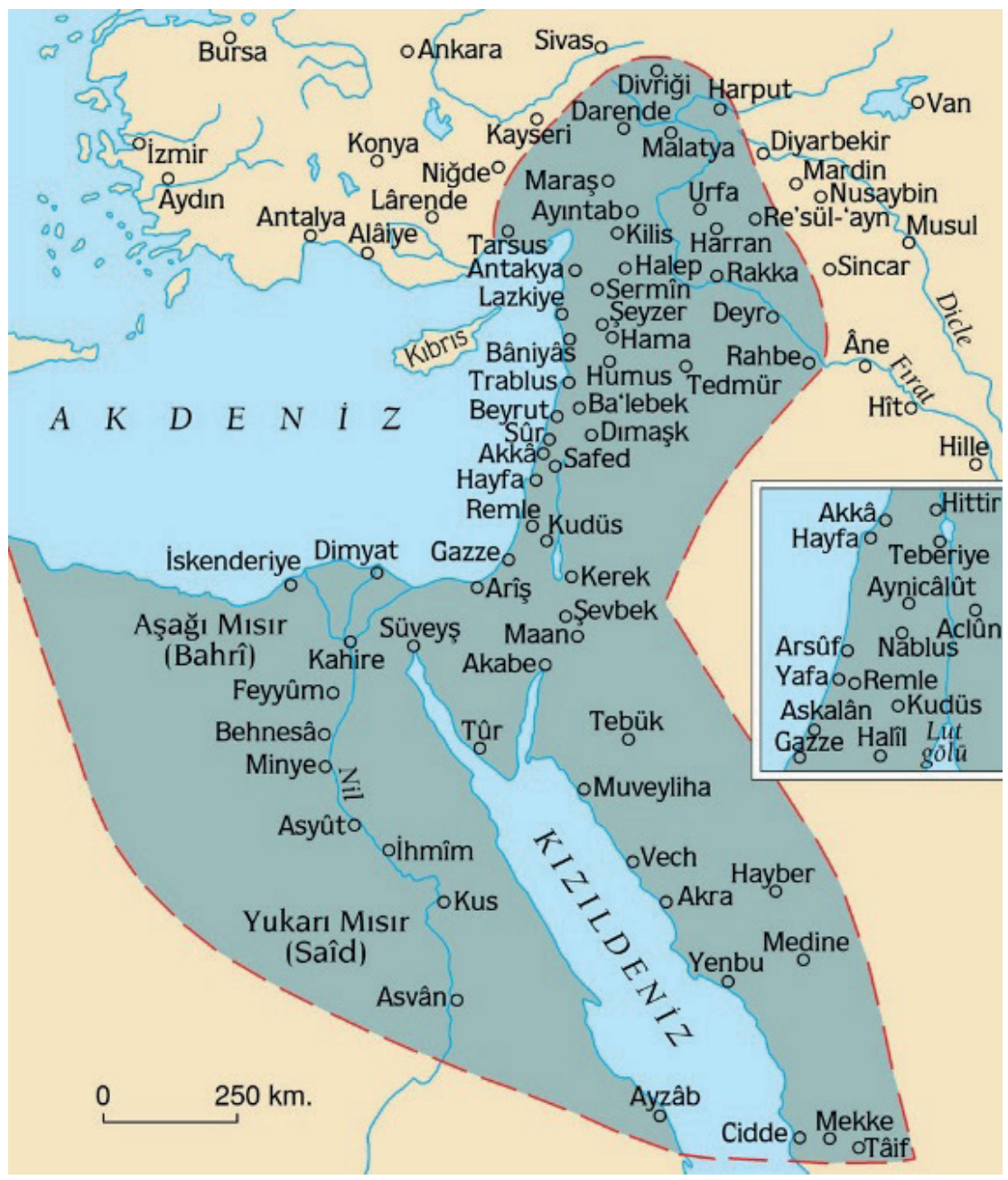


Memlükler'in hüküm sürdüğü tarih aralığı 648-923/1250-1517'dir. Söz konusu tarihleri göz önünde bulundurarak bu dönemde hadis ilminde eser telif eden âlimlerden tespit ettiklerimizin listesini vermek istiyoruz:

\begin{tabular}{|c|c|c|c|}
\hline \multicolumn{4}{|c|}{ Tablo 1: Memlükler Döneminde Hadis Telifi Olan Âlimler } \\
\hline & İsim & Vefat & Doğum Yeri \\
\hline 1 & İbn Teymiyye, Mecdüddîn & $652 / 1254$ & Harran \\
\hline 2 & Kurtubî, Ahmed b. Ömer & $656 / 1258$ & Kurtuba \\
\hline 3 & Münzirî, Ebû Muhammed & $656 / 1258$ & Kahire \\
\hline 4 & Reşid el-Attâr & $662 / 1264$ & Kahire \\
\hline 5 & Ebû Şâme el-Makdîsî, Abdurrahmân ed-Dımaşkî & $665 / 1267$ & Dımaşk \\
\hline 6 & İbnü's-Saykal, Ebü'l-Ferec en-Necîb b. Abdullatîf & $672 / 1274$ & Harran \\
\hline 7 & Mansûr b. Selîm & $673 / 1275$ & İskenderiye \\
\hline 8 & Nevevî, Ebû Zekeriyya & $676 / 1277$ & Nevâ (Suriye) \\
\hline 9 & İbnü’s-Sâbûnî, Ebû Hâmid & $680 / 1282$ & Cevvis (Basra) \\
\hline 10 & İbn Rüşeyk, Ebü’l-Hasan Muhammed & $680 / 1282$ & Dımaşk \\
\hline 11 & İbn Asâkir, Ebü'l-Yümn & $686 / 1287$ & Dımaşk \\
\hline 12 & Kastallânî, Muhammed b. Ahmed & $686 / 1287$ & Kahire \\
\hline 13 & İbnü’n-Nefîs, Ebü'l-Hasen Alâuddîn & $687 / 1288$ & Dımaşk \\
\hline 14 & Huveyyî, Muhammed b. Ahmed & $693 / 1294$ & Dımaşk \\
\hline 15 & Muhibbüddîn et-Taberî & $694 / 1295$ & Mekke \\
\hline 16 & Ahmed b. Muhammed el-Hüseynî & $695 / 1295$ & Haleb \\
\hline 17 & İbn Ferah, Ebü'l-Abbâs & $699 / 1300$ & İşbiliyye \\
\hline 18 & Kelâbâzî, Mahmûd b. Ebû Bekir & $700 / 1300$ & Kelâbâz (Buhâra) \\
\hline 19 & İbn Dakîku'l-Îd & $702 / 1302$ & Kûs (Misır) \\
\hline 20 & Dimyâtî, Abdülmü'min b. Halef & $705 / 1306$ & Tûne (Mısır) \\
\hline 21 & Taberî, Radiyüddîn İbrâhim b. Muhammed & $722 / 1322$ & Mekke \\
\hline 22 & İbn Teymiyye, Takıyyüddîn & $728 / 1328$ & Harran \\
\hline 23 & Ca‘berî, Burhânüddîn & $732 / 1332$ & Câber (Suriye) \\
\hline 24 & İbn Cemâ‘a, Bedrüddîn & $733 / 1333$ & Hama \\
\hline 25 & İbn Seyyidünnâs & $734 / 1334$ & Kahire \\
\hline 26 & Kutbüddîn el-Halebî (İbn Uhti’ş-Şeyh Nasr) & $735 / 1335$ & Haleb \\
\hline 27 & İbnü'l-Bârizî el-Hamevî & $738 / 1338$ & Hama \\
\hline 28 & Birzâlî, Ebû Muhammed & $739 / 1339$ & Dımaşk \\
\hline 29 & İbn Balabân, Alâüddîn & $739 / 1339$ & Kahire \\
\hline 30 & Hâzin, Ali b. Muhammed & $741 / 1341$ & Bağdat \\
\hline 31 & İbnü's-Sika es-Sayrafî & $742 / 1341$ & Musul \\
\hline 32 & Mizzî, Yusuf b. Abdurrahmân & $742 / 1341$ & Haleb \\
\hline
\end{tabular}




\begin{tabular}{|c|c|c|c|}
\hline 33 & Zeylâî, Osmân b. Ali & $743 / 1343$ & Zeyla' \\
\hline 34 & İbn Abdülhâdî, Şemsüddîn & $744 / 1343$ & Dımaşk \\
\hline 35 & İbn Abdülhak el-Vâsitî & $744 / 1344$ & Dımaşk \\
\hline 36 & Ebû Hayyân Esîrüddîn Muhammed b. Yûsuf el-Endelûsî & $744 / 1344$ & Matahşâreş (Gırnata) \\
\hline 37 & İbn Ğânâim, Cemâlüddîn Abdullah & $744 / 1344$ & Dımaşk \\
\hline 38 & İbnü'l-İmâm, Takıyyüddîn & $745 / 1344$ & Kahire \\
\hline 39 & Zehebî, Şemsüddîn & $748 / 1348$ & Dımaşk \\
\hline 40 & İbnü’l-Lebbân & $749 / 1349$ & Dımaşk \\
\hline 41 & Dimyâtî, Ebü'l-Hasan Ahmed b. Eybek & $749 / 1348$ & Dimyat \\
\hline 42 & İbnü’t-Türkmânî, Alâüddîn & $750 / 1349$ & Mardin/Kahire \\
\hline 43 & İbn Kayyim el-Cevziyye & $751 / 1350$ & Dımaşk \\
\hline 44 & Takıyyüddîn es-Sübkî, Ebü'l-Hasan Ali b. Abdilkâfî & $756 / / 1355$ & Menûfiye \\
\hline 45 & Alâî, Ebû Saîd & $761 / 1359$ & Dımaşk \\
\hline 46 & Moğultay b. Kılıç & $762 / 1361$ & Kahire \\
\hline 47 & Zeylâî, Abdullah b. Yûsuf & $762 / 1360$ & Zeyla \\
\hline 48 & Huseynî, Ebü'l-Mehâsin & $765 / 1364$ & Dımaşk \\
\hline 49 & İbn Hilâl el-Makdîsî & $765 / 1364$ & Kudüs \\
\hline 50 & $\begin{array}{l}\text { İbn Cemâ‘a, İzzüddîn Ebû Ömer Abdülazîz b. } \\
\text { Muhammed }\end{array}$ & $767 / 1366$ & Dımaşk \\
\hline 51 & İbn Ferhûn, Bedrüddîn & $769 / 1367$ & Medine \\
\hline 52 & Sübkî, Tâcüddîn & $771 / 1370$ & Kahire \\
\hline 53 & İbn Kesîr, Ebü’l-Fidâ & $774 / 1373$ & Busrâ/Dımaşk \\
\hline 54 & İbn Râfi', Ebü'l-Meâlî & $774 / 1372$ & Kahire \\
\hline 55 & Abdülkâdir b. Ahmed, Ebû Muhammed el-Kureşî & $775 / 1373$ & Kahire \\
\hline 56 & $\begin{array}{l}\text { İbn Merzûk el-Hatîb, Ebû Abdillah Muhammed b. } \\
\text { Ahmed }\end{array}$ & $781 / 1379$ & Tilimsân \\
\hline 57 & İbn Berdis, Ebü'l-Fidâ & $786 / 1384$ & Ba'lebek \\
\hline 58 & Kirmânî, Şemsüddîn & $786 / 1384$ & Kirman \\
\hline 59 & $\begin{array}{l}\text { İbnü'l-Küveyk er-Rib'î, Ebû Ca'fer Muhammed b. } \\
\text { Abdüllatîf }\end{array}$ & $790 / 1388$ & Tikrit/Misır \\
\hline 60 & Zerkeşî, Ebû Abdillâh Muhammed b. Abdillâh et-Türkî & $794 / 1392$ & Kahire \\
\hline 61 & İbn Receb el-Hanbelî & $795 / 1393$ & Bağdat \\
\hline 62 & Burhânüddîn et-Tenûhî & $800 / 1398$ & Tenuh/Dımaşk \\
\hline 63 & Münâvî, Sadrüddîn Ebü’l-Me‘âlî Muhammed b. İbrâhîm & $803 / 1401$ & Münye/Kahire \\
\hline 64 & İbnü’l-Mülakkın, Sirâcüddîn & $804 / 1401$ & Kahire \\
\hline 65 & Bulkînî, Sirâcüddîn Ebû Hafs Ömer b. Raslân & $805 / 1403$ & Kahire \\
\hline 66 & Irâkî, Zeynüddîn & $806 / 1404$ & Kahire \\
\hline 67 & Heysemî, Ebü'l-Hasen & $807 / 1405$ & Sahrâ (Misır) \\
\hline 68 & İbn Kunfüz, Ebü'l-Abbâs Ahmed b. el-Hüseyn & $810 / 1407$ & Kostantîne (Cezayir) \\
\hline
\end{tabular}




\begin{tabular}{|c|c|c|c|}
\hline 69 & İbn Cemâ‘a, Bedrüddîn Muhammed b. Ebî Bekir & $810 / 1407$ & Dimaşk \\
\hline 70 & Tüsterî, Nasrullah b. Ahmed & $812 / 1409$ & Bağdat \\
\hline 71 & İbn Hiccî, Şihâbuddîn & $816 / 1413$ & Dımaşk \\
\hline 72 & İbn Cemâ'a, Muhammed b. Ebû Bekir & $819 / 1416$ & Yenbu' \\
\hline 73 & Şümennî, Ebû Abdillah Muhammed b. el-Hasan & $821 / 1418$ & Mağrib/İskenderiye \\
\hline 74 & Merrâkûşî, İbn Mûsa & $823 / 1421$ & Mekke \\
\hline 75 & Bulkinî, Abdurrahmân b. Ömer & $824 / 1421$ & Kahire \\
\hline 76 & İbnü'l-Irâkî & $826 / 1423$ & Kahire \\
\hline 77 & Fâsî, Takıyyüddîn Muhamemd b. Ahmed el-Mekkî & $832 / 1429$ & Mekke \\
\hline 78 & İbnü'l-Cezerî, Şemsuddîn & $833 / 1429$ & Dimaşk \\
\hline 79 & İbnü’l-Kirmânî, Takıyyüddîn & $833 / 1430$ & Bağdat \\
\hline 80 & İbn Hatîbüddehşe, Ebü’s-Senâ & $834 / 1431$ & Hama \\
\hline 81 & Bûsîrî, Ahmed b. Ebû Bekir & $840 / 1436$ & Ebû Sîr (Misir) \\
\hline 82 & Sibt İbnü'l-Acemî & $841 / 1438$ & Haleb \\
\hline 83 & İbn Nâsırüddîn, Ebû Bekr & $842 / 1438$ & Dimaşk \\
\hline 84 & İbn Hacer el-Askalânî & $852 / 1449$ & Misir \\
\hline 85 & Aynî, Bedrüddîn & $855 / 1451$ & Ayintâb \\
\hline 86 & $\begin{array}{l}\text { İbnü'l-Hümâm, Kemâlüddîn Muhammed b. Abdülvâhid } \\
\text { es-Sivâsî }\end{array}$ & $861 / 1457$ & İskenderiye \\
\hline 87 & İbn Fehd, Takıyyüddîn & $871 / 1466$ & Asfûn (Misır) \\
\hline 88 & Münâvî, Şerefüddîn Yahyâ b. Muhammed & $871 / 1466$ & Kahire \\
\hline 89 & $\begin{array}{l}\text { Şümennî, Takıyyüddîn Ebu'l-Abbâs Ahmed b. } \\
\text { Muhammed }\end{array}$ & $872 / 1467$ & İskenderiye/Kahire \\
\hline 90 & Zeynüddîn, Abdulğanî b. Muhammed el-Ezherî & $882 / 1477$ & Misir \\
\hline 91 & Kâsım b. Kutluboğa, Zeynüddîn Ebü'l-Adl & $879 / 1474$ & Kahire \\
\hline 92 & $\begin{array}{l}\text { İbn Emîru'l-Hâc, Ebû Abdillâh Muhammed b. } \\
\text { Muhammed el-Halebî }\end{array}$ & $879 / 1474$ & Haleb \\
\hline 93 & Ebû Zer el-Halebî & $884 / 1480$ & Haleb \\
\hline 94 & Bikâî, Burhânüddîn & $885 / 1480$ & Bikâ (Lübnan) \\
\hline 95 & İbn Fehd, Ömer b. Muhammed el-Mekkî & $885 / 1480$ & Mekke \\
\hline 96 & İbnü’l-Haydırî, Ebu'l-Hayr & $894 / 1489$ & Dimaşk \\
\hline 97 & Nâcî, Burhânüddîn Ebû İshâk İbrâhim b. Muhammed & $900 / 1495$ & Dimaşk \\
\hline 98 & Sehâvî, Şemsuddîn & $902 / 1497$ & Kahire \\
\hline 99 & İbnü'l-Mibred, Cemâlüddîn & $909 / 1503$ & Dimaşk \\
\hline 100 & Semhûdî, Nûrüddîn & $911 / 1506$ & Semhûd (Misır) \\
\hline 101 & Süyûtî, Celâlüddîn & $911 / 1505$ & Kahire \\
\hline 102 & İbn Ebû Şerîf, Burhânüddîn & $923 / 1517$ & Kudüs \\
\hline 103 & Kastallânî, Ahmed b. Muhammed & $923 / 1517$ & Kahire \\
\hline
\end{tabular}


Memlükler döneminde hadis alanında eser veren muhaddisleri devletin kuruluş tarihi olan 648/1250 yılını göz önünde bulundurarak ele alacak olursak Memlükler'in kuruluşundan bir süre sonra vefât eden Mecdüddîn İbn Teymiyye (ö. 652/1254), Kurtuba'da doğmuş olmakla birlikte İskenderiye'ye yerleşen Ahmed b. Ömer el-Kurtubî (ö. 656/1258) ve yaşadığı yüzyılın en meşhur hadis hafızı kabul edilen Ebû Muhammed el-Münzirî (ö. 656/1258) ile başlatmamız gerekir. Söz konusu muhaddisler Eyyûbîler döneminde yetişmiş olmakla birlikte Memlükler kurulduğunda hayatta olan muhaddislerdir. Bu âlimler birkaç yılı hariç hayatlarının tamamını Eyyûbiler döneminde geçirmişlerdir. Bu yüzden, bunların yerine Memlükler yönetimi altında ilmî anlamda faaliyette bulunmaya yeterli bir zaman dilimi bulan âlimlerle Memlükler dönemi hadis âlimlerini tespit etmek aslında daha isabetli olacaktır. Söz konusu hususu göz önünde bulundurduğumuzda hayatının önemli bir bölümünü Eyyûbiler döneminde, 7 yıllık bir süresini Memlükler yönetimi altında geçiren Ebû Muhammed el-Münzirî’yi (ö. 656/1258) Memlükler döneminin önemli ilk hadis âlimi olarak gösterebiliriz.

Yaşadığı yüzyılın en meşhur hadis hâfızı kabul edilen Münzirî, yirmi yıl kadar hocalık yaptığı Eyyûbiler döneminde kurulan Kâmiliyye Dârülhâdis'i başta olmak üzere Sâlihiyye Medresesi ve Câmiu'z-Zâfirî' de verdiği derslerle pek çok hadis âlimi yetiştirmiş, İbn Hallikân (ö. 681/1282), Ali b. Muhammed el-Yûnînî (ö. 701/1302) ve İbn Dakîkul'Îd (ö. 702/1302) gibi Memlükler dönemi hadisçilerinin pek çoğuna hocalık yapmıştır. ${ }^{31}$ Muhtemelen bu özellikleri sebebiyle Münzirî bazı hadis tarihçileri tarafından hadis tarihinde bir dönemin bitişi ve yeni bir dönemin başlangıcını teşkil eden bir konuma yerleştirilmiştir. Nitekim Muhammed Ebû Zehv, el-Hadîs ve'l-muhaddisûn isimli eserinde hadis tarihini yedi dönemde ele almıştır. Bunlardan altıncısı hicrî 300'den başlayıp Münzirî’nin (ö. 656/1258) vefatına kadar devam eden dönemdir. Ebû Zehv’e göre yedinci dönem ise hadis tarihinin en uzun dönemini teşkil eden Münzirî’nin vefatından başka bir ifadeyle Memlükler asrından başlayıp günümüze kadar uzanmaktadır. ${ }^{32} \mathrm{Bu}$ dönemler çalışmamız boyunca esas aldığımız tasnifte "açılım”, "daralma” ve "yeni/dönüşüm” dönemlerine tekabül etmektedir.

Yukarıda tespit ettiğimiz 103 hadis âlimi hicrî VII-X. yüzyıllar arasında Memlükler sınırları içerisinde hadis eser(ler)i telif eden âlimlerdir. Bu âlimlerden hadis ilminde döneminin otoritesi olarak kabul edilen, eserleriyle sonrakileri etkileyen kanaatimize göre diğerlerine göre daha ön planda olan âlimler ise Münzirî, Nevevî, İbn Dakîkul‘Îd, Dimyâtî, İbn Cemâ‘a, Mizzî, Zehebî, İbn Kayyim el-Cevziyye, Takıyyüddîn es-Sübkî, Moğultay b. Kılıç, Zeylâî, Zerkeşî, İbnü'l-Mulakkın, Zeynüddîn Irâkî, Heysemî, Bûsîrî, İbn Hacer el-Askalânî, Bedrüddîn el-Aynî, Münâvî, Kâsım b. Kutluboğa, Sehâvî, Süyûtî ve Kastallânî'dir.

Dönemin son Buhârî şârihi Kastallânî, Memlükler'in yıkıldığı tarihte (923/1517) vefat etmiştir. Dolayısıyla o, Memlükler'in hadis alanında eser bırakan son âlimi olarak kabul

31 M. Yaşar Kandemir, "Münzirî”, Türkiye Diyanet Vakfi İslâm Ansiklopedisi (İstanbul: TDV Yayınları, 2006), 32/35.

32 Muhammed Ebû Zehv, el-Hadîs ve'l-Muhaddisûn ev İnâyetü'l-Ummeti'l-İslâmiyye bi 's-Sunneti'n-Nebeviyye (Riyad: er-Riâsetü'l-Âmmetu li-İdâreti'l-Buhûsi'l-İlmiyye ve'l-İftâi ve'd-Da'veti ve'l-İrşâd, 1984), 7. 
edilebilir. Memlük topraklarının Osmanlı hâkimiyetine geçmesiyle birlikte hayatlarının önemli bir kısmını Memlükler döneminde geçiren hadis âlimleri ise ilmî faaliyetlerini Osmanlı yönetimi altında devam ettirmişlerdir. Bu kategoride değerlendirebileceğimiz âlimlerden tespit ettiklerimizi de şu şekilde sıralayabiliriz:

\begin{tabular}{|c|c|c|c|}
\hline & İsim & Vefat & Doğum Yeri \\
\hline 1 & Zekeriyya b. Muhammed el-Ensârî & $926 / 1520$ & Süneyke (Misır) \\
\hline 2 & Nuaymî, Ebü’l-Mefâhir & $927 / 1521$ & Dımaşk \\
\hline 3 & İbnü'l-Keyyâl ed-Dımaşkî & $929 / 1523$ & Dımaşk \\
\hline 4 & $\begin{array}{l}\text { Ebü'l-Hasen el-Menûfî, Ali b. Muhammed el- } \\
\text { Misrî }\end{array}$ & $939 / 1532$ & Kahire \\
\hline 5 & $\begin{array}{l}\text { Şâmî, Şemsüddîn Ebû Abdillâh Muhammed b. } \\
\text { Yûsuf }\end{array}$ & $942 / 1536$ & Sâlihiyye (Dımaşk) \\
\hline 6 & Tetâî, Muhammed b. İbrâhîm el-Mâlikî & $937 / 1531$ & Menûfiye \\
\hline 7 & $\begin{array}{l}\text { Delecî, Ebü'l-Fazl Muhammed b. Muhammed } \\
\text { el-Osmânî }\end{array}$ & $950 / 1543$ & Kahire \\
\hline 8 & Bekrî, Ebü'l-Hasan es-Sıddîkî & $952 / 1545$ & Kahire \\
\hline 9 & $\begin{array}{l}\text { İbn Tolun, Ebû Abdillâh Muhammed b. } \\
\text { Muhammed ed-Dımaşkî }\end{array}$ & $953 / 1546$ & Salihiyye (Dımaşk) \\
\hline 10 & Bekrî, Cemâlüddîn & $962 / 1555$ 'ten sonra & Misır \\
\hline 11 & Abbâsî, Abdürrahîm & $963 / 1556$ & Kahire \\
\hline 12 & İbn Arrâk, Ebü'l-Hasan & $963 / 1556$ & Beyrut \\
\hline 13 & Alkâmî, Şemsüddîn & $969 / 1561-1562$ & Kahire \\
\hline 14 & Şa'rânî, Abdülvehhâb b. Ahmed el-Misrî & $973 / 1565$ & Kalkaşende \\
\hline 15 & İbn Hacer el-Heytemî & $974 / 1567$ & Misır \\
\hline
\end{tabular}

Hadis eğitimi almak isteyen birçok ilim tâlibi, Memlükler’in sınırları içerisinde bulunmamakla birlikte Horasan, Mâverâunnehir, Endülüs, Bağdat, Yemen ve daha birçok yerden Memlükler'in ilim merkezlerini dolaşmışlardır. Birçok âlim Bağdat, Musul, Kurtuba gibi sarsıntılı dönemler geçiren şehirlerden göç ederek güvenli bölge olan Memlükler sınırları içerisinde ilmi faaliyetlerini devam ettirmişlerdir. Endülüs asıllı olup çeşitli hadis âlimlerinden dersler alıp memleketlerine dönenler, dönmeyip hayatlarının geri kalanını Kahire veya Dımaşk’ta geçirenler olmuştur. Diğer İslâm beldelerinde doğup, Kâhire ya da Dımaşk'a uğramayan bu iki şehirdeki muhaddislerden istifade etmeyen bir hadisçi hemen hemen yok gibidir. Bu yüzden Memlükler'in kurulduğu tarihten yıkıldığ 1 tarihe kadarki zaman aralığında diğer bölgelerde yetişen muhaddislerin bir listesine de burada yer vermenin isabetli olacağı kanaatindeyiz. 


\section{Tablo 3: Hicrî VII.-X. Asırlar Arasında Memlük Sınırları Dışında Diğer İslâm Beldelerinde Yetișen Muhaddisler}

\begin{tabular}{|c|c|c|c|}
\hline & İsim & Vefat & Doğum Yeri \\
\hline 1 & Şarrî, Ebü’l-Hasan & $649 / 1251$ & Sebte \\
\hline 2 & Sağânî, Radiyuddîn & $650 / 1252$ & Lahor \\
\hline 3 & Hârizmî, Ebu'l-Mueyyed Muhammed b. Mahmûd & $655 / 1257$ & Havârizm \\
\hline 4 & İbnü’l-Ebbâr el-Belensî & $658 / 1260$ & Belensiye \\
\hline 5 & İbnü'l-Musdî el-Endelûsî & $663 / 1265$ & Vâdîaş (Gırnata) \\
\hline 6 & Kurtubî, Muhammed b. Ahmed & $671 / 1273$ & Kurtuba \\
\hline 7 & Şâtıbî, Muhammed b. Süleymân & $672 / 1274$ & Şâtibe \\
\hline 8 & Ali b. Enceb, Tâcüddîn el-Bağdâdî & $674 / 1276$ & Bağdat \\
\hline 9 & Mevsılî, Abdullah b. Mahmûd & $683 / 1384$ & Musul \\
\hline 10 & Eş’ârî, Ahmed b. Muhammed & $690 / 1291$ & Mâlik (Endülüs) \\
\hline 11 & İbnü'l-Buhârî, Ebü'l-Hasan Ali b. Ahmed & $690 / 1287$ & \\
\hline 12 & Debbâğ, Abdurrahmân b. Muhammed & $699 / 1300$ & Kayrevan \\
\hline 13 & İbn Ebû Cemre, Abdullah b. Sa'd & $699 / 1300$ & Endülüs \\
\hline 14 & Yûnînî, Ali b. Muhammed & $701 / 1302$ & Yûnîn (Ba'lebek) \\
\hline 15 & Kaşğ̂i, Muhammed b. Muhammed & $705 / 1306$ & $?$ \\
\hline 16 & İbnü’z-Zübeyr es-Sekafî & $708 / 1308$ & Ceyyân \\
\hline 17 & İbn Rüşeyd, Ebû Abdillah & $721 / 1321$ & Sebte \\
\hline 18 & İbnü'l-Fuvâtî, Kemâlüddîn & $723 / 1323$ & Bağdat \\
\hline 19 & Tücîbî, Ebü'l-Kâsım & $730 / 1329$ & Sebte \\
\hline 20 & Hatîb et-Tebrîzî, Ebû Abdullah Muhammed b. Abdullah & $741 / 1340$ & $?$ \\
\hline 21 & Tîbî, Ebû Muhammed & $743 / 1343$ & Tîb (İran) \\
\hline 22 & Vâdîaşî, Ebû Abdillah & $749 / 1348$ & Tunus (aslen Vâdîâş) \\
\hline 23 & Kâzerûnî, Ebû Sa‘d Sa‘îd b. Muhammed & $758 / 1357$ & Kâzerûn (Faris) \\
\hline 24 & Ebü'l-Hüseyn, Ahmed b. Ahmed el-Kürdî el-Hakkârî & $763 / 1362$ & Hakkari \\
\hline 25 & İbnü’l-Hâc en-Nümeyrî & $780 / 1378$ & Girnata \\
\hline 26 & İbnü’l-Akûlî, Gıyâsüddîn & $797 / 1394$ & Bağdat \\
\hline 27 & $\begin{array}{l}\text { Cürcânî, es-Seyyid eş-Şerîf Ebü'l-Hasan Ali b. } \\
\text { Muhammed }\end{array}$ & $816 / 1413$ & Cürcan \\
\hline 28 & Fîrûzâbâdî, Mecdüddîn & $817 / 1415$ & Şîrâz \\
\hline 29 & Ubbî, Ebû Abdillâh & $828 / 1425$ & Übbe (Tunus) \\
\hline 30 & Aclûnî, Muhammed b. Ahmed & $831 / 1427$ & Aclûn (Ürdün) \\
\hline 31 & Mücârî, Ebû Abdillah & $862 / 1458$ & Vâdîâş (Gırnata) \\
\hline 32 & Seâlibî, Ebû Zeyd & $875 / 1471$ & Vâdiyüsr (Cezayir) \\
\hline 33 & Âmirî, Yahyâ b. Ebî Bekr & $893 / 1488$ & Haraz (Yemen) \\
\hline 34 & Zebîdî, Ahmed b. Ahmed & $893 / 1488$ & Zebîd (Yemen) \\
\hline 35 & Muîn el-Miskîn & $907 / 1501-1502$ & Herat \\
\hline 36 & İbn Gâzî, Ebû Abdillah & $919 / 1513$ & Miknâs (Fas) \\
\hline
\end{tabular}




\section{Memlükler Dönemi Muhaddisleri Listesi Üzerine Bazı Değerlendirmeler:}

1. Memlükler döneminde hadis alanında eser veren 103 hadis âlimi tespit etmiş bulunmaktayız. ${ }^{33} \mathrm{Bu}$ listenin daha uzun vadede yapılacak araştırmalarla geliştirilmesi mümkündür.

2. Listede yer verdiğimiz âlimlerden bir kısmı İslâmî ilimlerin diğer alanlarında yetkin olmakla birlikte hadis alanında eser ya da eserler veren âlimlerdir. Memlük dönemi âlimlerinin büyük çoğunluğu İslâmî ilimlerin birçok alanında söz sahibi kimseler olmakla birlikte, listede yer verdiğimiz âlimlerin tamamının hadis ilimlerinde yetkin âlimler olduğu söylenemez. Nitekim yukarıda yer verdiğimiz isimlerden bazılarının hadis ilimlerine dair sadece bir ya da birkaç eseri bulunmaktadır. Meselâ bir hekîm olan ve çalışmalarının büyük çoğunluğu tıp üzerine olup hadis usulüne dair elMuhtasar fî ilmi usûli'l-hadîsi'n-nebevî isimli eseri kaleme alan İbnü'n-Nefîs (ö. 687/1288) de bu listede yer almaktadır.

3. 15 muhaddis hayatlarının bir bölümünü Memlük ilim mirası içerisinde Memlük medreselerinde, Memlük idaresi altında geçirmiş olup hayatlarının büyük çoğunluğunu Mısır'in Osmanlı hâkimiyeti döneminde sürdürmüştür.

4. Yukarıdaki listelere bakılacak olursa Memlükler'in hâkim olduğu hicrî yedinci asrın ikinci yarısından hicrî onuncu asrın ilk çeyreğine kadarki dönemde Memlükler sınırları içerisinde yetişen hadis ilminde telif sahibi âlimlerin sayısı o dönem tüm İslâm dünyasının çeşitli beldelerdeki âlimlerin iki katından fazladır. Bu durum söz konusu asırlarda Memlükler'in hadis ilmindeki üstünlügünü ortaya koymaktadır. Bununla birlikte Abbasiler sonrasında hadis ilminde pek çok muhaddisin yetiştiği Horasan $^{34}$ ve Mâverâunnehir bölgeleri ile Bağdat ve Kûfe gibi şehirlerde neredeyse eser veren bir hadis âlimi yok gibidir.

5. Memlük hâkimiyeti olmayan bölgelerde hadis ilminde eser telif eden 36 muhaddisin ismi tespit edilebilmektedir. Yine daha detaylı araştırmalarda bu sayının daha da artacağı kanaatindeyiz. Tespit edilen veya edilecek âlimler ve eserleri üzerine ya da Memlükler asrında diğer bölgeler üzerine yapılacak çalışmalar hem hadis tarihine hem de hadis edebiyatına önemli katkılar sağlayacaktır.

33 Bu isimleri başta Türkiye Diyanet Vakfi İslâm Ansiklopedisi olmak üzere Kettânî'nin er-Risâletü'l-Müstatrafe, Mücteba Uğur'un Hadis Illimleri Edebiyatı ve Ali Yardım'ın Hadis I-II isimli eserlerinden tespit ettik.

34 "Horasan, doğu İslâm âlemini tehdit eden Cengiz istilâsına ilk maruz kalan yerlerden birisi idi. Moğolların eline düşen şehirler yağmaya uğradı, özellikle Merv ve Nişâbur gibi istilâcılara karşı direnen şehirlerde katliam ve tahribat korkunç boyutlara ulaştı. Bu istilâ hareketi halkın göç etmesine, nüfusun iyice azalmasına ve bütün üretim mekanizmasının bozulmasına, konulan keyfî vergiler de geriye kalan halkın daha fazla fakirleşmesine yol açtı. Cengiz Han, Horasan şehirlerinin yeniden imarına izin vermemiş, ölümünden sonra hânedan mensuplarının ortak malı kabul edilen bir emirlik haline getirilmiş, daha sonra 654/1256 yılında kurulan İlhanlılar'ın yönetimine bırakılmıştır. İlhanlılar'ın başşehirlerini Batı İran-Azerbeycan topraklarına taşımaları ilim, sanat, edebiyat ve siyaset merkezlerinin Horasan'dan Batı'ya intikal etmesi, Horasan'ın ekonomik ve kültürel üstünlügünü kaybetmesi sonucunu doğurmuştur." Osman Çetin, "Horasan", Türkiye Diyanet Vakfi İslâm Ansiklopedisi (İstanbul: TDV Yayınları, 1998), 18/237. 
6. Yukarıda verdiğimiz ilk listede yer alan muhaddislere baktığımızda büyük çoğunluğunun Mısır menşeli oldukları görülmektedir. Mısır'da özellikle Kâhire, daha sonra Dımaşk en çok muhaddisin yetiştiği iki şehir konumundadır.

7. Yukarıda isimlerini verdiğimiz hadis ilminde eser bırakan Memlük âlimlerinin birçoğu hoca-talebe ya da akran ilişkisinin bulunduğu âlimlerdir. Memlükler'in ilk dönemlerindeki âlimlerle son dönem âlimleri arasında bir silsile şeklinde ilişki kurulabilmektedir. Memlükler'de hadis âlimlerinin bu ilişkisi müstakil araştırmalara konu olacak mâhiyettedir. İlmî mirâsın intikalinde ve devamında bu silsilenin büyük bir önemi olduğunu düşünüyoruz. ${ }^{35}$

8. Memlük muhaddisleri arasındaki bu hoca-talebe silsilesi ilişkisi hadis edebiyatına tesir etmiş olmalıdır. Birçok talebenin hocalarının kitaplarına yazdığı şerhler, ihtisarlar ve zeyillerde hocalarının hocalarına ait kitaplar üzerine yaptıkları çalışmalarda bu silsilenin önemli bir rolü vardır. Örneğin Memlükler'in ilk âlimi olarak yukarıda yer verdiğimiz Münzirî’nin öğrencilerini takip ettiğimizde Memlükler'in yıkılışından sekiz yıl önce yani 909 yılında doğan ve 974 yılında vefat eden İbn Hacer elHeytemî’ye kadar ulaşmaktayız. Bu silsileyi şöyle gösterebiliriz:

Münzirî (ö.656/1258)

Dimyâtî (ö. 705/1306)

Mizzî (ö. 742/1341)

Takıyyüddîn es-Sübkî (ö. 756/1355)

Zeynüddîn el-Irâkî (ö. 806/1404)

İbn Hacer el-Askalânî (ö. 852/1449)

Zekeriyya el-Ensârî (ö. 926/1520)

İbn Hacer el-Heytemî (ö. 974/1567)

Memlükler'in en velûd yazarlarından Süyûtî'nin hocalarını takip ettiğimizde İbn Hacer ile yukarıdaki silsileye bağlandığını, son âlimi Kastallânî’ye kadar uzanan hoca talebe silsilesinin takip ettiğimizde hocası Sehâvî'nin İbn Hacer el-Askâlânî'nin öğrencisi olduğunu ve yine yukarıdaki silsileye bağlandığını görmekteyiz.

9. Yukarıda isimlerini verdiğimiz Memlük âlimlerininden birçoğu üzerine çeşitli araştırmalar yapılmıştır. “Türkiye' de Memlükler Dönemi Hadis Çalışmaları” isimli makalemizde 2013 yılına kadar tespit ettiğimiz eser, araştırma ve incelemelere yer verilmiştir. ${ }^{36}$ Memlükler ile ilgili her geçen gün yeni araştırmaların yapılıyor olması bu çalışmanın güncellenmesini gerekli kılmaktadır. Bu şekilde ortaya çıkan tabloda eksik kalan alanlarla ilgili akademik araştırmaların teşvik edilmesinin genelde hadis tarihi özelde Memlük tarihi açısından önemli ve gerekli olduğunu düşünmekteyiz.

35 Konuyla ilgili bir çalışma yakın zamanda doktora tezi olarak tamamlanmıştır. Ahmet Eşer, Hadis Illminde Fehrese Literatürü (İstanbul: İstanbul Üniversitesi Sosyal Bilimler Enstitüsü, Doktora Tezi, 2021).

36 Ferhat Gökçe, “Türkiye'de Memlükler Dönemi Hadis Çalışmaları”, Türkiye Araştırmaları Literatür Dergisi 11/21 (2013), 41-88. 


\section{Memlükler Dönemi Hadis Eserlerinin Hadis Literatürünün Türlerine Göre Dağılımı:}

Yukarıda isimlerini zikrettiğimiz Memlük âlimlerinin hadis ilimlerine dair 1201 eserini tespit ettik. Bunlardan bir kısmı matbu, bir kısmı yazma halinde, bir kısmı ise kaynaklarda kendilerine nispet edilenlerden oluşmaktadır. Hicrî VII-X. asır arasında Memlükler döneminde yaşayan âlimlerin hadis ilmine dair telif ettikleri eserleri vefat tarihlerine, yazarlarına ve konularına göre listeledik. ${ }^{37}$ Yapılacak kapsamlı bir çalışmada bu listenin daha da geliştirileceği ve zenginleştirilebileceği kanaatindeyiz. Biz burada sadece bu 1201 eserin hadis edebiyatının türlerine göre dağılımını içeren listesini sunmak istiyoruz. Bu rakamın dönemin tasnif anlayışı, tasnifin yoğunlaştı̆̆ı alanlar, tasnifin temel unsurları ve hususiyetleri gibi konularda bir değerlendirme yapmamıza imkân tanıyacağını düşünüyoruz:

37 Makalemizin hacmini aşacağından bu listeye burada yer veremeyeceğiz. İleride yapmayı planladığımız kapsamlı bir araştırmada bu listeye yer vermeyi düşünmekteyiz. 


\begin{tabular}{|c|c|c|c|c|}
\hline \multicolumn{5}{|c|}{ Tablo 4: Memlükler Dönemi Hadis Literatürünün Türlere Göre Dağılımı ${ }^{38}$} \\
\hline \multirow{29}{*}{1} & \multirow{29}{*}{ Hadis Metinleri/Derlemeler } & Ahkâm & 48 & \multirow{29}{*}{459} \\
\hline & & Avâlî & 21 & \\
\hline & & Cüz & 13 & \\
\hline & & Emâlî & 14 & \\
\hline & & Erbaûn & 60 & \\
\hline & & Etrâf & 17 & \\
\hline & & Hadis Derlemeleri & 71 & \\
\hline & & Humâsiyyât & 1 & \\
\hline & & Kudsî Hadis & 1 & \\
\hline & & Kütüb-i Sitte & 18 & \\
\hline & & Meşhûr & 5 & \\
\hline & & Mevdûât & 19 & \\
\hline & & Mu'cemü'ş-Şüyûh & 84 & \\
\hline & & Müselsel & 9 & \\
\hline & & Müsned & 2 & \\
\hline & & Mütevâtir & 2 & \\
\hline & & Sahîhâyn & 13 & \\
\hline & & Sübâiyyât & 2 & \\
\hline & & Sülâsiyyât & 2 & \\
\hline & & Sümâniyyât & 2 & \\
\hline & & Sünâiyyât & 1 & \\
\hline & & Şemâil & 7 & \\
\hline & & Tefsîr & 2 & \\
\hline & & Terğîb ve Terhîb & 7 & \\
\hline & & Tibbü'n-Nebevî & 4 & \\
\hline & & Tüsâiyyât & 6 & \\
\hline & & Uşâriyyât & 1 & \\
\hline & & Zayıf Hadisler & 1 & \\
\hline & & Zevâid & 26 & \\
\hline 2 & Hadis Usulü & Hadis Usulü & 85 & 85 \\
\hline
\end{tabular}

38 Bu tabloda kullanılan hadis literatürü türleri Mücteba Uğur'un Hadis Illimleri Edebiyatı isimli eserinden tespit edilmiştir. Uğur'un alfabetik olarak tespit ettiği hadis literatür türleri “Hadis Metinleri Derleme”, "Hadis Usulü”, "Hadis Ricâli", "Hadis Şerhleri”, "Hadis İlimleri”" gibi üst başlıklarda toplanmış, hem sened hem de metinle ilgili olabilecek doğrudan bu türlerden herhangi birisi ile ilişkilendiremediğimiz literatür ise "Diğer/Çeşitli Konular" başlığg altında bir araya getirilmiştir. 


\begin{tabular}{|c|c|c|c|c|}
\hline \multirow{16}{*}{3} & \multirow{16}{*}{ Hadis Ricâli } & Cerh ve Ta'dîl & 3 & \multirow{16}{*}{247} \\
\hline & & Duafâ & 12 & \\
\hline & & Elkâb & 3 & \\
\hline & & Ensâb & 5 & \\
\hline & & Esmâ ve Künâ & 5 & \\
\hline & & Muhtelit & 2 & \\
\hline & & Mü'telif ve'l-Muhtelif & 4 & \\
\hline & & Mübhemât & 6 & \\
\hline & & Müdellis & 3 & \\
\hline & & Müştebih/Müteşâbih & 8 & \\
\hline & & Ricâlü'l-Hadîs & 60 & \\
\hline & & Sahâbe & 30 & \\
\hline & & Sikat & 8 & \\
\hline & & Şehir Tarihi & 26 & \\
\hline & & Tabakât & 45 & \\
\hline & & Tevârîh ve Vefeyât & 27 & \\
\hline \multirow{2}{*}{4} & \multirow{2}{*}{ Hadis Şerhleri } & Hadis Şerhi (Tek ya da birkaç) & 67 & \multirow{2}{*}{157} \\
\hline & & Hadis Şerhleri & 90 & \\
\hline \multirow{6}{*}{5} & \multirow{6}{*}{ Hadis İlimleri } & Esbâbü Vürûdi'l-Hadîs & 1 & \multirow{6}{*}{35} \\
\hline & & Garîbü'l-Hadîs & 8 & \\
\hline & & İlelü’l-Hadîs & 20 & \\
\hline & & Muhtelifü'l-Hadîs & 3 & \\
\hline & & Müşkilü’l-Hadîs & 1 & \\
\hline & & Nâsihü'l-Hadîs ve Mensûhuhu & 2 & \\
\hline \multirow{15}{*}{6} & \multirow{14}{*}{ Diğer/Çeşitli Konular } & Bid'at & 1 & \multirow{14}{*}{218} \\
\hline & & Fetâva'l-Hadîsiyye & 4 & \\
\hline & & Fevâid & 3 & \\
\hline & & Hadis Kitapları Üzerine & 40 & \\
\hline & & Hasâis & 19 & \\
\hline & & Kussâs & 2 & \\
\hline & & Muhadram & 2 & \\
\hline & & Müdrec & 1 & \\
\hline & & Mürsel & 7 & \\
\hline & & Siyer & 33 & \\
\hline & & Sünne & 3 & \\
\hline & & Tahrîc & 58 & \\
\hline & & Tertîb & 9 & \\
\hline & & Turuku'l-Hadîs & 36 & \\
\hline & & Toplam & & 1201 \\
\hline
\end{tabular}


$\mathrm{Bu}$ genel tablodan sonra hem Memlükler dönemi hem de hadis tarihinin en önemli isimlerinden birisi olan İbn Hacer el-Askalânî’nin (ö. 852/1449) hadis çalışmalarının listesine de burada yer vermek istiyoruz. Şâkir Mahmûd Abdulmün'im, İbn Hacer'in 282'den fazla eser telif ettiğini tespit etmiştir. ${ }^{39}$ İbn Hacer'in öğrencilerinden Sehâvî hocasının biyografisini el-Cevâhir ve'd-dürer fì tercemeti Şeyhi'l-İslâm İbn Hacer isimli eserinde bir araya getirmiş ve burada çok önemli bilgiler vermiştir. Sehâvî aynı zamanda İbn Hacer'e ait, tespit ettiği ve haklarında kısa bilgiler de verdiği 273 eserinin listesini vermiştir. ${ }^{40}$ Bunlardan 21 'i tarih, 29'u fıkıh, 1'i usûlü'd-Dîn, 1'i fikıh usûlü, 16'sı ise Arap dili, arûz ve edebiyata, 205'i ise hadis ilmine dairdir. Sehâvî, bunları hadis literatürünün çeşitli alanlarına göre sıralamıştır. M. Yaşar Kandemir ise İbn Hacer'in hadis ilmine dair 172 eserini aynı şekilde hadis ilminin çeşitli alanlarına göre sıralamıştır. ${ }^{41}$ Şimdi öncelikle İbn Hacer'in ilgilendiği tüm ilim dallarındaki çalışmalarını tespit etmeye çalışan Şâkir Mahmûd Abdülmün 'îm' in verdiği eserlerin dökümünü aktaralım:

\begin{tabular}{|l|c|}
\hline \multicolumn{2}{|c|}{ Tablo 5: İbn Hacer'in Eserlerinin İlim Dallarına } \\
Göre Dağılımı
\end{tabular}

39 Şâkir Mahmûd Abdülmun 'im, İbn Hacer el-Askalânî, musannefâtuhu ve dirâsetu fí menhecihi ve mevâridihî fí Kitâbi'l-İsâbe (Beyrut: Müessesetü'r-Risâle, 1997), 167-386.

40 Şemsuddîn Muhammed b. Abdirrahmân es-Sehâvî, el-Cevâhir ve'd-dürer fí tercemeti Şeyhi 'l-İslâm İbn Hacer, thk. İbrâhim Bâcis Abdülmecîd (Beyrut. Dâru İbn Hazm, 1999), 2/659-695.

41 M. Yaşar Kandemir, "İbn Hacer el-Askalânî”, Türkiye Diyanet Vakfi İslâm Ansiklopedisi, (İstanbul: TDV Yayınları, 1999), 19/517-530. 


\begin{tabular}{|l|c|}
\hline Mu'cem-Meşyeha & 11 \\
\hline Fehrese & 7 \\
\hline Ricâl & 22 \\
\hline Terâcim-Menâkib & 7 \\
\hline Tarih & 17 \\
\hline Arap Dili ve Lügat & 13 \\
\hline Şiir ve Divan & 3 \\
\hline Muhtelif Konular & 3 \\
\hline Ecvibe & 13 \\
\hline Toplam & $\mathbf{2 8 2}$ \\
\hline Nispet edilenler & $\mathbf{3 8}$ \\
\hline
\end{tabular}

Sehâvî ve Kandemir'in vermiş oldukları listeye göre İbn Hacer'in eserlerinin hadis literatürünün türlerine göre dağılımı şu şekildedir:

\begin{tabular}{|l|c|c|c|}
\hline \multicolumn{3}{|c|}{ Tablo 6: İbn Hacer'in Hadis Alanındaki Eserlerinin Hadis Literatürünün Türlerine Göre } \\
Dağllımı
\end{tabular}

Memlük dönemi muhaddislerinin hepsinin bu kadar farklı alanlarda yoğunlaşıp eser verdikleri söylenemez. Ancak İbn Hacer'in yukarıdaki çalışmaları dönemin hadis çalışmalarının hadis edebiyatı içerisindeki yoğunlaştığı alanları âdeta özetlemekte, bizlere hadis ilminde en üst düzeyde/mertebede bulunan bir muhaddisin hadis ilmindeki ilgi alanlarını göstermektedir. 


\section{Memlükler Dönemi Hadis Literatürünün Değerlendirilmesi:}

1. Memlükler döneminin $118(103+15)$ muhaddisi üzerinde yaptığımız çalışmada 1201 eser tespit etmiş bulunmaktayız.

2. Tespit ettiğimiz 1201 eserin bir kısmı el yazma halinde, bir kısmı ise kaynaklarda isimleri belirtilen veya nispet edilen eserlerden oluşmaktadır.

3. Memlükler döneminde hadis ilmine dair telif edilen 1201 eseri "hadis metinleri/ derlemeler" (459), "hadis usûlü” (85), "hadis ricâli” (247), "hadis şerhleri” (157), "hadis ilimleri" (35) ve "diğer çeşitli konular" (218) isimli başlıklarda toplamak mümkündür. Bu tablodan dönemin çalışmalarının hadis derlemeleri, hadis ricâli ve hadis şerhleri üzerinde yoğunlaştı̆̆ı anlaşılmaktadır.

4. Memlükler dönemi hadis edebiyatının "hadis şerhleri” (90), "hadis usulü” (85) "hadis derlemeleri” (71), "tek hadis şerhleri” (67), "ricâl” (60), "tahrîc” (58), "ahkâm” (48), "tabakât" (45), "erbaûn" (40), "turuku'l-hadîs" (36), "vefeyât" (27), "zevâid" (26), "şehir tarihi” (26), "mevdûât" (19) ve "etrâf" (17) alanlarında yoğunlaştığı görülmektedir.

5. Yukarıdaki tabloyu incelediğimizde en fazla telif edilen hadis edebiyatı türünün 157 eserle hadis şerhleri olduğu görülmektedir. Hadis kaynakları üzerine yazılan 90, tek ya da birkaç hadis şerhinden oluşan 67 eser tespit edilmiştir. Daha sonra sırasıyla 85 eserle "hadis usulü", 71 eserle "hadis derlemeleri", yine hadis derlemeleri altında değerlendirebileceğimiz 60 eserle "kırk hadis”lerin geldiğini görmekteyiz.

6. Bu tablo Memlükler'in içerisinde bulunduğu dönemlerin "derleme ve şerh" 42 dönemi olarak değerlendirilmesinin somut bir işareti olarak değerlendirilebilir. Nitekim tarafımızdan hicrî altıncı asır üzerine yapılan bir çalışma Memlükler döneminden bir önceki asrın daha çok derleme dönemi olduğunu göstermiştir. ${ }^{43}$ Derlemelerin bir sonraki aşaması şerhler olduğundan altıncı asırdan itibaren şerhlerin sayısı gittikçe artmış, Memlükler döneminde zirveye ulaşmıştır.

7. Memlükler dönemi hadis edebiyatının en dikkat çeken ve en başarılı görülen türü şerhlerdir. Bu döneminde özellikle Buhârî ve Müslim üzerine birçok şerh ve ihtisar çalışması yapılmıştır. Çalışmamızda tespit ettiğimiz kadarıyla Memlükler döneminde Buhârî'nin el-Câmi ine 34, Müslim'in el-Câmi ine 15, el-Muvattả üzerine 4, Ebû Dâvûd'un es-Sünen'ine 17, Tirmizî'nin el-Câmi 'ine 7, Beyhakî'nin Kitâbü 'ssüneni' 'l-kebîr' ine 6, Nesâî'nin es-Sünen'ine 1, Begavî'nin Mesâbîhu's-sünne'sine 6, Şerhu's-sünne'sine 1 ve Ahmed b. Hanbel'in el-Müsned'i üzerine 1 “şerh-ihtisar" çalışması yapılmıştır.

42 Ansiklopedik hadis şerhlerinin verildiği Memlükler dönemini tanımlamada "şerhçilik dönemi" ifadesine katılmadığımızı, "şerh" ile "şerhçiliği" birbirinden ayırdığımızı belirtmemiz gerekir. Nitekim şerh faaliyeti ile şerhçilik farklı hususlardır. Şerhçilik kavramı hadis tarihinin duraklama dönemine daha uygun düşmektedir. Nitekim bu dönemde artık şerh türü eserlerin de örnekleri durmuş, önceki yazılan şerhler esas alınmıştır. Şerhlerden sonra yoğun hâşiye geleneği de şerhçiliğin bir tezahürü olarak değerlendirilebilir.

43 Ferhat Gökçe, “Ali b. Osman el-Ûş̧̂̀nin Yaşadığı Dönemde Hadis İlmi”, Uluslararası Ali b. Osman el-Ûş̂̂̉ Sempozyumu Bildirileri (Bişkek: Oş İlahiyat Fakültesi Yayınları, 2018), 459-490. 
8. Hadis edebiyatını, senet ve metne dayalı çalışmalar şeklinde temelde iki kısımda değerlendirecek olursak Memlükler döneminde isnâda taalluk eden ilimlerde çalışmalar devam etmekle birlikte metne yönelik araştırma ve incelemelerin, metin merkezli çalışmaların ağırlıklı olduğunu söyleyebiliriz. Şüphesiz hadis edebiyatının durumu sadece eserlerin sayısına göre değerlendirilemez. Ancak bu alanda önemli bir çabanın verildiği bir gerçektir. Öte yandan hicrî dördüncü asırdan itibaren ilerleyerek gelişen şerh faaliyeti, başka bir ifadeyle şerh kapsamına giren hadislerin açıklanması (tefsir), anlaşılması ve yorumlanması meselesi dönemin en temel meselesi olarak görünmektedir.

9. Sadece Müslim şerhlerinin en önemli ve en iyilerinden birisi olarak kabul edilen fakih ve muhaddis Nevevî’nin (ö. 676/1277) el-Minhâc fî şerhi Sahîh-i Müslim b. Haccâc isimli eseri, fakih, tarihçi, dilbilimci ve tenkitçi Buhârî’nin Sahih'i üzerine Moğultay b. Kılıç’ın (ö. 762/1360) şerhi; fakih, usûlcü, kelâmc1, müfessir ve dilbilimci olarak nitelenen Kirmânî’nin (ö. 786/1384) şerhi, fıkıh, tarih ve biyografi uzmanı İbn Hacer (ö. 852/1449) ve tarihçi usulcü ve fikıh âlimi Aynî’nin (ö. 855/1451) şerhleri toplamda 100 cildi aşmaktadır. Tüm bu şerhlere bakıldığında bunların ağırlıkı olarak “ilmü dirâyeti'l-hadîs"e odaklı olduğu görülmektedir. ${ }^{44}$ Tüm bu eserler müelliflerinin çok yönlü âlimler olmasının da etkisiyle zengin içerikli ansiklopedik hadis çalışmaları arasındaki yerini almıştır.

10. Memlükler döneminde yazılan hadis şerhleri "metin odaklı" hadisçiliğin nasıl hadis alanının çekim merkezi haline geldiğini göstermeye kâfidir. ${ }^{45}$

11. Önceki dönemlerde görülmeyen birçok tasnif türünün ilk örnekleri Memlükler döneminde verilmiştir. Bunların en başta geleni zevâidlerdir. ${ }^{46}$ Zevâid edebiyatı üzerine yapılan yoğun çalışmaları göz önünde bulunduran bazı hadis tarihçileri bu dönemi "zevâid dönemi” olarak nitelendirmişlerdir. Nitekim hadis tarihini 8 dönemde ele alan ve Türkiye' de ilk hadis tarihi kitabı olarak bilinen İzmirli İsmâil Hakkı'nın Hadis Tarihi isimli eserinde hadis tarihinin son iki dönemi hadis edebiyatı merkeze alınarak "zevâid türü eserler devri” ve "zevâid sonrası dönem” şeklinde değerlendirilmiştir. ${ }^{47}$

12. Ricâl ve tabakât alanında da bu dönemde çok çalışma yapılmıştır. Hadis ricâline dair 60, mu'cemü'ş-şüyûh'a dair 84, tabakât alanına dair 45, tarih ve vefeyât alanında 27 eser tespit etmiş bulunmaktayız. Bu durum muhaddislerinin bu dönemde bir yandan isnâda taalluk eden ricâl ilmine dair çalışmalarla da ilgilendiklerini göstermektedir. Tespit etmiş olduğumuz 40 eserin önemli bir kısmı başta Buhârî ve Müslim'in el-

44 Özafşar, "Hadis İlminde Alan Evrilmesi”, 115.

45 Özafşar, "Hadis İlminde Alan Evrilmesi”, 115.

46 Büyük çoğunluğu Memlükler döneminde telif edilen zevâid türü eserler için bk. Abdullah Karahan, Hadis Edebiyatında Zevâid Kitapları (İstanbul: Sır Yayınları, 2005).

47 İzmirli İsmail Hakkı, Hadis Tarihi, nşr. İbrahim Hatiboğlu (İstanbul: Dârulhadis, 2002), 283. 
Câmi 'leri olmak üzere temel hadis kaynaklarının ricâli üzerine yapılan çalışmalardan oluşmaktadır. Memlükler döneminde yapılan ricâl çalışmaları “dirâyetü’l-hadîs"in bu dönemde metin ağırlıklı olmakla birlikte isnâd çalışmalarıyla birlikte yürütüldüğünü de göstermektedir.

13. Yukarıdaki tabloda verilen rakamları biraz daha incelediğimizde dönemin tamamına yayılamayacak, belli kişilerde toplanan çalışmalardan söz edebiliriz. Örneğin “ilelü'l-hadîs”e dair tespit ettiğimiz 20 çalışma Memlükler'in tamamında ilgilenilen bir alan olarak değerlendirilmemelidir. Bununla birlikte "ilel”in müstakil bir ilim disiplini olarak ele alındığı ilk çalışma İbn Receb'in (ö. 795/1393) Şerhu 'İleli’tTirmizî isimli eseridir. İbn Receb bu eserinde Tirmizîn'nin çalışmasını ilavelerle genişletmiş, eksikliklerini tamamlayarak şerh ve tenkit etmiş, eserin sonunda ilel ilmiyle ilgili bazı bilgilere ve kurallara bir bölüm ayırmıştır. ${ }^{48}$

14. İlel çalışmalarının büyük çoğunluğu İbn Hacer el-Askalânî’ye ait olup, o bu alanda tespit ettiğimiz 20 eserin 18 'ini telif etmiştir. ${ }^{49}$ Diğer bir çalışma ise talebesi Sehâvî (ö. 902/1497) tarafından Dârekutnî’nin İlel'i üzerine yapılan bir ihtisar çalışmasıdır. Öte yandan İbn Hacer el-Askalânî'nin Buhârî şerhi Fethu'l-bârî bi-şerhi Sahîhi'lBuhârî'si ile el-Hidâye hadislerinin şerhine dair Zeylâî'nin (ö. 762/1360) Nasbü'rrâye li-tahrîci ehâdîsi'l-Hidâye'si ilel konusunda her ne kadar temelde ilel türü eserler olmasa da hadislerdeki illetler konusunda müracaat edilmesi gereken kaynaklar arasındadir.

15. Hadis edebiyatının bazı türlerinin ilk örnekleri Memlük muhaddisleri tarafından verilmiştir. Başta "zevâid” olmak üzere, "tahrîc”, "turuku'l-hadîs”, "el-fetâva'lhadîsiyye"50, "esbâbü vürûdi'l-hadîs" ve halk dilinde hadis olarak şöhret bulan sözlerin ele alındığ 1 "meşhûr" türünün ilk örnekleri bu döneme aittir.

16. "Ale'l-ahruf" dediğimiz hadislerin alfabetik olarak sıralandığg hadis mecmualarının ilk örneklerini de Memlük âlimleri vermiştir. Bedrüddîn ez-Zerkeşî (ö. 794/1392), halk dilinde hadis olarak dolaşan sözleri topladığı et-Tezkire fi'l-ehâdîsi'l-müşstehire isimli eserinde hadisleri alfabetik olarak sıralamıştır. ${ }^{51}$ Hadis metinlerini ilk kelimelerine göre alfabetik olarak sıralayan Süyûtî (ö. 911/1505), bu sistemle el-Câmi 'u'ssağîr' de 10.031 hadisi kaynaklarına ve sıhhat durumlarına işaret etmek suretiyle

48 Cengiz Kallek, “İbn Receb”, Türkiye Diyanet Vakfi İslâm Ansiklopedisi (İstanbul: TDV Yayınları, 1999), $20 / 245$.

49 M. Yaşar Kandemir, "İbn Hacer el-Askalânî”, 19/519-520.

50 Ahmet Yücel, el-Fetâvâ'l-hadîsiyye'nin ilk örneğini İbnü’s-Salâh'ın Fetâvâ ve Mesâil'i olduğunu belirtmektedir. Bununla birlikte eser sadece hadis fetvalarına hasr edilmiş değildir. Eserde akâid, tefsir ve fikıhla ilgili sorular da yer almaktadır. Yücel, Hadis Tarihi, 156. Mehmet Görmez ise fikhü’l-hadîs’in bir türü olarak değerlendirdiği Fetâvâ'l-hadîsiyye türünün ilk örneğini İbn Teymiyye'nin verdiğini kaydetmiştir. Mehmet Görmez, "F1khü'lHadîs", Türkiye Diyanet Vakfi Íslâm Ansiklopedisi (İstanbul: TDV Yayınları, 2006), 12/548. Hadis fetvalarıyla ilgili literetür için bk. Yavuz Köktaş, Hadis Fetvaları Literatürü, Özellikleri ve Örnekleri (İstanbul: Rağbet Yayınları, 2017).

51 İsmail Lütfi Çakan, Hadis Edebiyatı: Çeşitleri, Özellikleri, Faydalanma Usulleri (İstanbul: Marmara Üniversitesi İlahiyat Fakültesi Yayınları, 1985), 121. 
toplamış bulunmaktadır. ${ }^{22}$ Yine Süyûtî, Cem 'u'l-cevâmi 'de de 100.000 hadisi bir araya getirmiştir. ${ }^{53}$

17. Hadis usulündeki telifler sadece Memlükler dönemini değil yazıldıktan sonra hadis usulünde yapılan tüm çalışmaları etkisi altında bırakan İbnü’s-Salâh'ın (ö. 643/1245) Mukaddime'si temelinde hazırlanmıştır. Yazılan eserler ya doğrudan bu eserin bir şerhi, ya bu esere yazılan bir ihtisarın şerhi, ya nazım haline getirilmiş şekli ya da bu nazmın şerhlerinden ibaret olan çalışmalardır. Tüm bu çalışmalarda bulunan âlimler İbnü's-Salâh'ın eserini olduğu gibi aktarmamışlar ya da gelişi güzel kısaltmamışlardır. Ona bir takım tenkitlerde ya da ilavelerde bulunmuşlardır. ${ }^{54}$ Mesele müstakil çalışmalara konu olacak mâhiyettedir.

18. Memlükler döneminde mevzû hadisler üzerine yapılan çalışmalar dikkat çekmektedir. Mevzû hadislere dair telif edilen eserlerin birçoğu İbnü'l-Cevzî’nin (ö. 597/1201) el-Mevzû 'ât'ı temelinde hazırlanmıştır. Zeynüddîn el-Irâkî (ö. 806/1404), İbn Hacer el-Askalânî (uö. 852/1449) ve Süyûtî’nin (ö. 911/1505) bu alanda çalışmaları vardır. ${ }^{55}$ Söz konu hadis âlimleri yaptıkları çalışmalarında İbnü'l-Cevzî'nin tespit edemediği mevzû hadisleri tespit etmişler ve onun mevzû olarak nitelendirdiği bazı hadislerin mevzû olmadığını savunmuşlardır.

19. İlk defa Memlükler döneminde telifini gördüğümüz türlerden birisi halk arasında yaygın olan (ya da hadis olarak bilinen) sözlerle ilgilidir. Bedrüddîn ez-Zerkeşî (ö. 794/1392) et-Tezkire fi'l-ehâdîsi'l-müştehire isimli eseriyle bu türün ilk örneğini vermiştir. ${ }^{56}$ Daha sonra İbn Hacer el-Askalânî, Sehâvî ve Süyûtî de bu alanda çeşitli çalışmalar kaleme almışlardır. ${ }^{57}$

20. Kütüb-i Sitte üzerine yapılan çalışmaların tespit ettiğimiz 18 eserden ibaret olduğu düşünülmemelidir. Memlükler dönemi, Kütüb-i Sitte' den özellikle Sahîhayn başta olmak üzere Kütüb-i Sitte'nin diğer eserlerine birçok çalışmanın yapıldığı bir dönem olmuştur. Zira Memlükler döneminden bir önceki asırda 1stılah olarak kullanılmaya başlanan "Kütüb-i Sitte” 1stılahı -her ne kadar bazı âlimler farklı görüşler belirtseler de- İbn Mâce'nin es-Sünen'ini de içine alacak şekilde artık yerleşmiştir.

21. Söz konusu tespit ettiğimiz 18 çalışma ayrı ayrı Kütüb-i Sitte’ yi oluşturan kitaplar üzerine değil, Kütüb-i Sitte’yi bir bütün olarak ele almaktadır. Kütüb-i Sitte râvîleri üzerine ilk önemli çalışmayı yapan Cemmâilli’nin (ö. 600/1203) el-Kemâl fì esmâ 'i’r

52 Halit Özkan, "Süyûtı̂”, Türkiye Diyanet Vakfi İslâm Ansiklopedisi (İstanbul: TDV Yayınları, 2010), 38/191.

53 Özkan, "Süyûtî", 38/191.

54 Ali Arslan, “Mukaddimetü İbni’s-Salâh İsimli Eser Üzerine Yapılan Çalışmalar”, 2462-2463.

55 M. Yaşar Kandemir, "el-Mevzûât”, Türkiye Diyanet Vakfi İslâm Ansiklopedisi (Ankara: TDV Yayınları, 2004), 29/497-498.

56 İsmail Lütfi Çakan, Hadis Edebiyatı, 121.

57 Mücteba Uğur, Hadis İlimleri Edebiyatı (Ankara: TDV Yayınları, 1996), 172-173; Gökçe, “Türkiye'de Memlükler Dönemi Hadis Çalışmaları”, 72-73. 
ricâl'i Kütüb-i Sitte râvîleriyle ilgili yapılan çalışmalarda temel alınan eser olmuştur. ${ }^{58}$ Bu alanda Mizzî'nin (ö. 742/1341) Tehzîbü'l-Kemâl fí esmâ 'i'r-ricâl isimli çalışması tam bir şâheserdir. Zehebî (ö. 748/1348), Ebü'l-Mehâsin el-Hüseynî (ö. 765/1364), Sıbt İbnü'l-Acemî (ö. 841/1438) ve İbn Hacer el-Askalânî (ö. 852/1449) gibi âlimler el-Mizzî’nin bu kitabı üzerine çalışmalarda bulunmuşlardır.

22. Memlükler dönemi hadis edebiyatında esas alınan bazı eserler vardır. Bunların en başta geleni Kütüb-i Sitte'dir. Kütüb-i Sitte dışında çeşitli alanlarda temel alınan bazı eserler üzerine yoğun çalışmalar yapıldı̆̆ı görülmektedir. Bunlardan bir kısmı Memlükler öncesi âlimlerin eserleridir. Bir kısmı ise Memlük âlimlerinden olup talebeleri ya da daha sonraki Memlük âlimleri tarafından esas alınmıştır. Aşağıda listesini vereceğimiz eserler birçok Memlük âliminin üzerinde, şerh, hâşiye, zeyl, muhtasar türü çalışmalar yaptıkları alanlarında otorite ya da zirve olarak kabul edilmiştir.

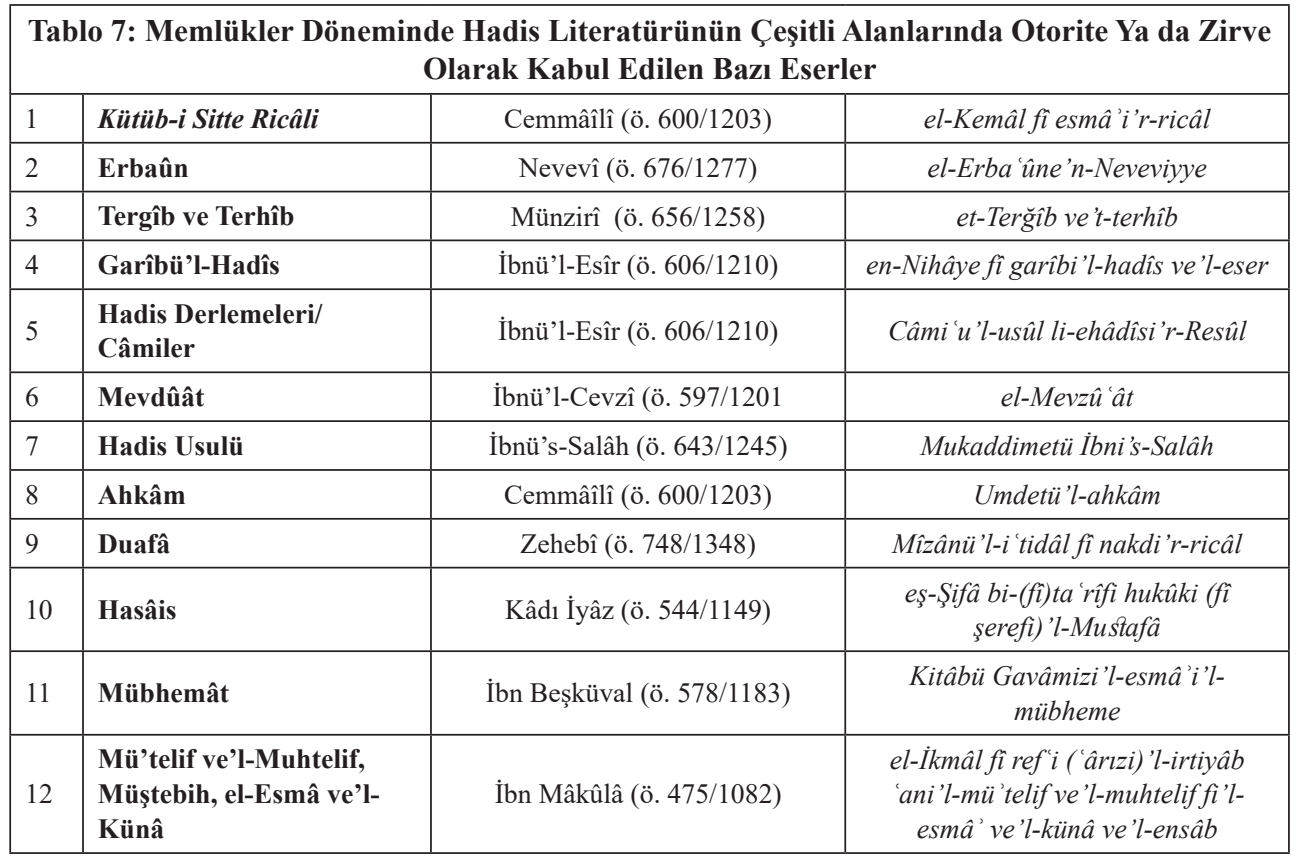

23. Hadislerin metinlerine yönelik ilim dallarında Memlükler döneminde yapılan çalışmalara da işaret etmek gerekir. "Esbâbü vürûdi'l-hadîs” ilminde günümüze ulaşan ilk eser, Süyûtî (ö. 911/1505) tarafından telif edilmiştir. ${ }^{59}$ Eserde fikıh bâblarına göre siralanan sadece 98 hadisin -farklı rivâyetleriyle birlikte- vürûd sebepleri ele

58 Erdoğan Köycü, el-Mizzî’nin Hadis İlmindeki Yeri, (Ankara: Araştırma Yayınları, 2013).

59 Ramazan Ayvallı, "Esbâbü Vürûdi'l-Hadîs", Türkiye Diyanet Vakfi İslâm Ansiklopedisi (İstanbul: TDV Yayınlar1, 1995), 11/362-363. 
alınmış olsa da, "esbâbü vürûdi'l-hadîs" 1stılahının bir literatür türü olarak hadis edebiyatına girmiş olması önemlidir.

24. Yukarıdaki tabloda en az telif verilen alanların muhtelifü'l-hadîs, müşkilü'l-hadîs, fikhü'l-hadîs ve garîbü'l-hadîs gibi hadis metinlerine yönelik ilimlerden ibaret olduğunu görmekteyiz. Hadis metinlerine önem verilen ve yapılan çalışmaların metinler üzerinde yoğunlaştığı bir dönemde bu ilim dallarına ait eserlerin az oluşu, bu ilimlerde bir çabanın gösterilmediği anlamına gelmemektedir. Zengin hadis şerhlerinin örneklerini veren Memlük âlimleri bu ilimleri şerhini yaptıkları kitapların ilgili gördükleri hadisleri üzerinde kullanmışlardır.

25. Hadis edebiyatına dair hicrî VII. asırdan sonra fikhü'l-hadîs ilminin kapsamında değerlendirebileceğimiz "el-fetâva'l-hadîsiyye" türü kitaplar telif edilmeye başlanmıştır. ${ }^{60}$ Hadislere dair çeşitli fetvâları içeren bu tür kitaplar toplumun hadise ilgisini, hadisle ilgili meraklarını, sorularını ve cevaplarını ihtiva etmesi bakımından çok önemli bilgilere ulaşabileceğimiz kaynaklar arasındadır. ${ }^{61}$

26. Memlükler döneminde en çok telif edilen türlerinden birisi "mu'cemü'ş-şüyûh" ya da "fehrese"lerdir. Bu tür eserler bir muhaddisin görüşüp hadis aldığg hocalarının isimlerini, onların biyografilerini, onlardan rivâyet icâzeti alınan eserlerin listesini ihtiva etmektedir. Fehreseler daha çok âlimlerin hocalarından okudukları kitapların alfabetik olarak kaydedildiği eserlerdir. ${ }^{62}$ Bu türde memlükler döneminde tespit ettiğimiz 80 eser bulunmaktadır.

27. Hadis edebiyatının ürünleri yoğunluklu olarak Kahire ve Dımaşk’ta verilmiştir. Ancak Kahire'deki ilmî atmosfer daha yüksektir. Bu atmosferin hadis edebiyatına ciddi bir etkisi vardır. Bunun bir örneğini Bedruddîn el-Aynî’de (ö. 855/1451) görmekteyiz. Aynî’nin hadis ilminde telif ettiği ilk eseri bir duâ ve ezkâr kitabı olan İbn Teymiyye'nin (ö. 728/1328) el-Kelimü't-tayyibe min ezkâri'n-nebî isimli eserine yazdığı el-Alemu'l-heyyib fì şerhi'l-Kelimi 't-tayyib isimli bir ciltlik şerhtir. ${ }^{63}$ Henüz Kahire'ye gelmeden önce telif ettiği bu çalışması ile büyük âlimlerle tanıştıktan sonra Kâhire ortamında yazdığı hadis şerhleri arasında ciddi bir fark vardır. Bu durum bizlere bir yandan bir hadis şârihinin bireysel/ilmî gelişimiyle şerhteki gelişimi arasındaki ilişkiyi diğer yandan eserin yazıldığı ortamın rolünü göstermektedir. Nitekim Aynî’nin

60 Görmez, "F1khü'l-Hadîs", 12/548.

61 Konunun detayları hakkında bk. Halit Özkan, Memlüklerin Son Asrında Hadis, 170-179.

62 M. Yaşar Kandemir, "Fehrese", Türkiye Diyanet Vakfi İslâm Ansiklopedisi (İstanbul: TDV Yayınları, 1995), $12 / 297$.

63 Bedruddîn el-Aynî, el-Alemu'l-heyyib fî̀ şerhi Kelimi 't-tayyib, thk. Hâlid İbrâhim el-Misrî (Riyad: Mektebetü'rRüşd, 1998). 
'Umdetü' l-kârî' de hadis şerhinde takip ettiği yöntemin zenginliğinde ${ }^{64}$ bulunduğu ilmî ortamın, tanıştığı eserlerin, dönemin âlimlerinin tartıştığı meselelerin büyük bir rolünün olduğunu düşünüyoruz. Muhtemelen Aynî, Antep’ten Dımaşk’a, oradan Kâhire'ye gitmemiş olsaydı 'Umdetü'l-kârî gibi bir eser ortaya çıkmayacaktı.

\section{Sonuç}

On dört asırlık İslâm tarihinin iki buçuk asrında İslâm dünyasının ilim merkezi olma sıfatıyla hüküm süren Memlükler Devleti'nde hadis edebiyatında iz bırakan birçok âlim yetişmiş bu âlimler verdikleri eserlerle hadis edebiyatının zenginleşmesine ve gelişmesine katkıda bulunmuşlardır.

Kanaatimizce Memlük dönemi hadis edebiyatını şekillendiren en önemli faktör hadis ilminin tarihi seyri içerisindeki ulaştığ 1 konum olmuştur. Önceki asırlarda hadis musennefâtının tamamlanması, temel hadis kaynaklarının otoritelerini güçlendirerek yaygınlaşmış olması hatta bu temel kaynaklar üzerine yapılan derleme eserlerin de şöhret bularak birer klasik haline gelmesi, dönemin muhaddislerini şerhlere, ihtisarlara, zevâidlere, zeyillere ve etrâf türü çalışmalara yönlendirmiştir.

Tarihçilerin de belirtmiş olduğu Moğol ve Haçlı etkisinden de söz edilebilir. Moğollar ve Haçlıların birçok İslâm mirasını yok etmiş olmaları, İslâm müelliflerini birçok alanda ansiklopedik çapta eser yazmaya, önceki mirası koruma amaçlı bu mirası sahiplenerek bunlar üzerinde çalışmalar yapmaya teşvik etmiştir.

Âlimler arasındaki ilmî rekabetin de yapılan çalışmaların şekillenmesinde rolü olmuştur. Nitekim bu durumun dönemin âlimlerinin eserlerine yansıdığını müşahede etmekteyiz. SüyûtîSehâvî, İbn Hacer-Bedrüddîn el-Aynî arasındaki ilmî münakaşalar bunun en bariz örneklerini teşkil etmiştir.

Hicrî ilk dört asırda görülen orijinal mesailer bu dönemde pek verilmemişse de yoğun bir yazım faaliyeti sürekli olarak devam etmiştir. Bu yüzden dönemin bir gerileme dönemi olduğu söylenemez. Ebû Zehv’in İslâm dünyasında Memlükler hâkimiyetini içine alan dönemi "zirvede kalma" dönemi olarak nitelendirmesi daha isabetli görünmektedir. Hicrî VII, VIII ve IX. asırlar hadis edebiyatı açısından bir gerileme dönemi değildir. Nitekim bu dönemlerde hadis edebiyatının pek çok alanında yoğun çalışmalar yapılmıştır. Bu dönemin daha isabetli bir şekilde konumlandırılması gerekmektedir. Memlükler döneminin hadis faaliyetlerinin her alanında hicrî X, XI ve XII. asırlara nispetle ciddi bir üstünlüğü bulunmaktadır. Dolayısıyla

64 Aynî, eserinde hadisleri ele alırken az çok değişiklikler yapsa da ilk bâb için takip ettiği yöntemde hadis şerhini 30 başlıkta gerçekleştirmiştir. Sakallı, Aynî ve Hadis Yorum/Şerh Yöntemi, 72-75; Aynî hadis şerhlerinde şu başlıklara yer vermektedir: terceme izahı, lügat açıklamaları, i'râb açıklamaları, me ânî ilmi açısından açıklama, bedi“ ilmi açısından açıklama, beyân ilmi açısından açıklama, tefsir ilmi açısından açıklama, hadisin âyetle ilgisi, hadisin bâb başlığı ile ilgisi, sorular ve cevaplar, senedde yer alan râvîlerin açıklanması, râvîlerle ilgili diğer noktaların ortaya konulması, senedin ihtiva ettiği bazı özellikler, hadisin türünün açıklanması, hadisin Buhârî’de nerelerde geçtiği, hadisi eserlerine almış olan öteki hadisçiler, hadisten çıkarılabilecek fikhî hükümler, senedin ihtivâ ettiği bazı özellikler, hadisle ilgili belirtilmesinde fayda görülen diğer meseleler. Söz konusu başlıkların değerlendirilmesi hakkında bk. Zişan Türcan, Hadis Şerh Geleneği (Ankara: TDV Yayınları, 2011), 272-273. 
hadis tarihinde ve hadis edebiyatında bir gerilemeden bahsedilecekse bunu X. asrın son çeyreğinden itibaren başlatmak kanaatimizce daha uygundur.

Memlükler döneminin, literatürü dikkate alacak olursak altıncı asırda örneklerini gördüğümüz derleme faaliyetleri devam ettiği için "derleme"; dönemin temel yazım usulü şerhe dayandığı için "şerh" ve bu ikisinin birleşimiyle "derleme ve şerh" dönemi olarak nitelendirilmesi daha uygundur. $\mathrm{Bu}$ isimlendirme ya da değerlendirme, dönemin hadis edebiyatının genel karakteristiğini yansıttığı için objektif bir tanımlamadır. Ancak literatürün tamamını göz önünde bulundurduğumuzda "şerh" ön plana çıkmakta, coğrafî bakımdan bir daralmaya karşılık ilmî bakımdan bir genişleme ya da "açılım" kendisini bâriz bir şekilde hissettirmektedir. Bu yüzden Memlükler dönemi tam anlamıyla hadis ilmi ve hadis literatürü açısından bir "açılım" dönemidir.

Senetsiz hadis nakletme geleneği takriben hicrî beşinci asrın sonlarına doğru başlamıştır. $\mathrm{Bu}$ durum bir bakıma hadis metinleri yönünden kaynak eserler döneminin bittiği anlamına gelmektedir. Nitekim tasnif dönemi mahsullerinden musannef, câmî', sünen, müsned, mu 'cem, müstedrek ve müstahrecler hadis edebiyatında kaynak eserleri oluştururlar. Hadis derlemeciliği ve şerh dönemlerinde ortaya çıkan derleme, zevâid, tahrîc, etrâf, cem' çalışmaları ise kaynak hüviyeti olmayan ikinci el kaynak konumundadırlar. Özellikle hadis mütehassısları dışındaki araştırmacılar için bu ikinci devir eserler daha kullanışlı bir durum arz etmektedir. ${ }^{65}$

Memlükler öncesi dönemde hadis ilminin pek çok alanında zirveye ulaşan eserlerin telif edilmiş olması bu dönemde orijinal eserlerin telif edilmesinin önündeki en büyük engel olmuştur. Bu yüzden Memlük âlimleri çalışmalarını zirve olarak gördükleri bu eserler üzerinden sürdürmüşler ya da bunları temel alan kitaplar üzerinde yoğunlaşmışlardır. Şüphesiz bir eserin zirve ya da otorite olarak görülüp yeni ve güncel çalışmalara engel teşkil edecek bir rol oynaması yönündeki bir düşüncenin çeşitli yönleriyle tartışılması gerekmektedir. Ancak vakıa odur ki bu dönemde çeşitli alanlarda otorite ya da zirve olarak kabul gören kitaplar vardır. Burada bazı örneklerine yer verdiğimiz Memlükler döneminde telif edilen kitapların birçoğu için bunu dile getirebiliriz. Örneğin garîbü'l-hadîs ilminin en mükemmel eseri hicrî altıncı asırda İbnü'l-Esîr'in en-Nihâye'si ile verilmiştir. Kendisinden sonra gelenler ise yeni bir garîbü'l-hadîs kitabı yazmak yerine bundan istifade etmişler ve bunun üzerine çalışmalar yapmışlardır. Memlükler dönemi hadis edebiyatının bu bakış açısıyla değerlendirilmesinin yerinde olacağı kanaatindeyiz.

Memlükler döneminde dirâyetü'l-hadîs alanında önemli gelişmeler yaşanmıştır. Hicrî altıncı asrın sonlarından itibaren ilmu rivâyeti'l-hadîs devrini tamamlamış onun yerine hadis ilminin eksenine metin ağırlıklı ilmu dirâyeti'l-hadîs gelmiştir. Memlükler dönemi hadis literatürünün ya da ilmu dirâyeti'l-hâdîs' in metin merkezli çalışmalara yoğunlaşmasıyla, metin merkezli çalışmaların niteliği ayrı hususlardır ve bu nitelik ayrı bir araştırmanın konusudur. Metnin ele alınması yani metne dayalı çalışmalar, her dönemin kendi koşulları içerisinde değerlendirilmelidir.

65 Ali Yardım, Hadis I-II, 2/116, 121. 
Hadislerin açıklanması (tefsir), anlaşılması ve yorumlanmasına dair çalışmalar bu dönemde zirveye ulaşmıştır. "Şerh" metne dayalı hadis ilimlerinin (garîbü'l-hadîs, muhtelifü'l-hadîs, müşkilü'l-hadîs, nâsihü'l-hadîs, esbâbü vürûdi'l-hadîs) yürütüldügü genel bir kavramdır. $\mathrm{Bu}$ ilimlerin şerh literatürü içerisinde yürütülmesi hadis ilimlerini şerhleri yapılan hadislere münhasır kılmış, bu ilimlerin müstakil bir alan ya da problem olarak görülüp ele alınmasını geciktirmiş, bu da hadis ilimlerinde müstakil eserler verilmesinin önündeki en büyük engel olmuştur.

Örneğin fikhü'l-hadîs terimini el-Hâkim en-Nîsâbûrî'den (ö. 405/1014) XIX. yüzy1lda Cemâlettin el-Kâsımî’ye (1866-1914) kadar hadis ilimleri arasında zikreden olmamıştır. ${ }^{66} \mathrm{Bu}$ durum Memlükler döneminde fikhü'l-hadîse dair hiçbir çabanın gösterilmediği anlamına gelmemektedir. Nitekim hadis şârihleri hadis şerhlerinde fikhü'l-hadîse müracaat etmişlerdir. ${ }^{67}$ Ancak bu çaba temel alınan eserin ilgili görülen hadislerinin şerhi esnasında, şerh dâhilinde yürütülen bir faaliyet olmuştur. Kanaatimize göre bu durum söz konusu ilimlerin müstakil bir ilim olarak görülmesini engellemiştir. Aynı durum muhtelifü'l-hadîs ve müşkilü'l-hadîs ilimleri için de söz konusudur. Öyle ki bu ilimlerde hicrî dördüncü asırdan sonra telif edilen bir eserle hemen hemen karşılaşamamaktayız. ${ }^{68}$

Memlük hadis âlimlerinin birçoğu ansiklopedist âlimlerdir. Birçoğu hadis ilminin tek bir alanında değil birçok alanında çeşitli eserler telif etmişlerdir. ${ }^{69}$ Hadis ilminin yanında, diğer ilimlerle de uğraşmış bu ilim dallarında da çok sayıda eser vermişlerdir. Memlük muhaddisleri hadisçi kimliklerinin yanında aynı zamanda iyi bir dil âlimi, usûlcü, fakîh ve iyi bir tarihçidirler. Birçok alanda tasnif faaliyetlerini sürdüren âlimlere onların bu yönü özellikle şerh faaliyetlerinde büyük bir avantaj sağlamıştır. Ancak bu avantajın yanı sıra ansiklopedist olmanın dezavantajlarından da söz edilmelidir. Birçok alanla muhatap olan ansiklopedist hadis âlimleri çalışmalarını daha çok şerhlere teksif etmişler, bu da kanaatimizce onların fikhü’l-hadîs, muhtelifü'l-hadîs gibi ilim dallarında daha derinlemesine yoğunlaşamamalarına sebep olmuştur.

Dönemin en önemli vasıflarından birisi aslında bir önceki asırda başlayan "hadis derlemeciliğgi"nde önemli eserlerin verilmiş olmasıdır. Bu dönemde yazıldığı dönemden günümüze kadar rağbet gören üzerine çokça çalışmalar yapılan derlemeler kaleme alınmıştır. Hadis edebiyatında Nevevî'nin (ö. 676/1277) el-Erba 'ûn, Riyâzü's-sâlihîn ve el-Ezkâr'1, Münzirî'nin (ö. 656/1258) et-Tergîb ve't-terhîb'i İbn Hacer'in (ö. 852/1449) ahkâm hadisleri derlediği Bulûğu'l-merâm'ı asırlar boyu kullanılagelmiş ve başka eserlere nasip olmayan bir şöhrete ulaşmıştır.

İslâm dünyasının Memlükler döneminde oldukça büyük sıkıntılar geçiren Horasan/ Mâverâünnehir ve İspanya'daki hadis faaliyetleri üzerine elimizde yeterli araştırmalar

66 Mehmet Görmez, "F1khü’l-Hadîs”, 12/548.

67 Türcan, Hadis Şerh Geleneği, 240-250; Yavuz Köktaş, Fethu'l-Bârî ve Umdetu'l-Kârî'nin Metin Tahlili Açısından Incelenmesi (İstanbul: İsam Yayınları, 2009), 126-186.

68 Mücteba Uğur, Hadis Illimleri Edebiyatı, 192, 212-213.

69 Memlükler dönemi âlim ve muhaddis profili üzerine yapılan bir çalışma için bk. Nagihan Emiroğlu, "Memlüklerde Hadis ve Ulema", İslam Tetkikleri Dergisi 10/1 (2020), 365-387. 
bulunmamaktadır. Memlükler döneminde Moğolların işgali altında bulunan Bağdat, o dönem ilim dünyasında âdeta hiç ortada görünmeyen Kûfe, Basra, Semerkant, Buhâra ve Yemen gibi bölgelerde hâdis ilminin durumu hakkında net bilgilere sahip değiliz. Bu bölgelerde yetişen az da olsa muhaddislerin varlığını biliyoruz. Söz konusu bölgelerde yetişen hadis âlimlerinin Memlük ilim merkezleri ve âlimleri ile ilişkisi; Dımaşk, Kahire, Mekke ve Medine’ye yaptıkları yolculuklarının mâhiyetini ayrıntılı olarak ele alacak çalışmalara ihtiyaç olduğunu düşünmekteyiz. Bu çalışmalar sadece Memlükler dönemini değil, o dönem İslâm dünyasında hadis ilminin durumunu daha da netleştirecektir. İhtiyaç duyduğumuz bu çalışma hicrî VII, VIII ve IX. asırlarda hadisin durumunu, hadis ilminde yapılan çalışmaları daha kapsamlı bir şekilde görmemizi sağlayacaktır.

Şu an elimizde Memlükler döneminde hadis ilinde eser veren kaç âlimin bulunduğu, bu âlimlerin eserlerinin sayısı, bunların ne kadarının yayımlandığı, el yazma halinde bulunanların ne kadar olduğu ile ilgili veriler ve bilgilerin yer aldığı kapsamlı bir araştırma bulunmamaktadır. 1989 yılında Memlükler dönemine tahsis edilmemekle birlikte bu dönemi de içerisine alan bir literatür çalışması Mamut Yeşil tarafından yüksek lisans tezi olarak hazırlanmıştır. Bu çalışmada hadis edebiyatının hicrî VII. - X. asırları ele alınmıştır. Ancak o tarihten günümüze yayımlanan eserlerin sayısı önemli oranda artmış, Memlük âlimlerine ait bir takım el yazmalar gün yüzüne çıkmıştır. Dolayısıyla genel olarak hadis edebiyatının VII.-X. asırlarını içerisine alan yeni çalışmalara ihtiyaç duyulmaktadır.

Türkiye Diyanet Vakfi İslâm Ansiklopedisi’nde tespit edebildiğimiz kadarıyla Memlükler döneminde hadis alanında eser kaleme alan âlimlerin 88'inin biyografilerine yer verilmiştir. Ansiklopedide yer verilmeyip eser sahibi olduğunu tespit ettiğimiz 14 âlim daha bulunmaktadır. $\mathrm{Bu}$ âlimlerin yanı sıra hadis ilminde eserleri olup da bu ansiklopedide biyografileri bulunmayan âlimler/muhaddisler belirlenmeli, bu âlimler üzerine araştırmalar yapılmalıdır.

Ülkemizde hazırlanan hadis edebiyatına dair kitaplarda bu dönemin sadece en önemli ürünleri tanıtılmıştır. Memlükler dönemi hadis edebiyatı, bu dönem ve âlimleri üzerine çalışmaları bulunan araştırmacıların bir ekip halinde hadis edebiyatı ve hadis tarihi gibi alanlarda incelemelerde bulunmasının oldukça gerekli olduğunu düşünüyoruz. Yapılacak çalışma bu dönemin edebiyatını sadece bir liste sunarak ya da iki buçuk asırlık dönemi genel bazı vasıflandırmalarla değerlendirerek geçiştirmemeli, Memlükler'e dair kapsamlı bir literatür araştırması somut verilere dayanan, hadis edebiyatını şekillendiren siyasi, sosyal, kültürel, ilmî etkenlerin rolünü belirleyecek, çeşitli ilim dallarının hadis ilmi ile ilişkisini ve ilimler arası ilişkilerin hadis edebiyatındaki etkisini ortaya koyabilecek bir nitelikte olmalıdır.

Hakem Değerlendirmesi: Dış bağımsız.

Çıkar Çatışması: Yazar çıkar çatışması bildirmemiştir.

Finansal Destek: Yazar bu çalışma için finansal destek almadığını beyan etmiştir.

Peer-review: Externally peer-reviewed.

Conflict of Interest: The author has no conflict of interest to declare.

Grant Support: The author declared that this study has received no financial support. 


\section{Kaynakça/References}

Abdulmun'im, Şâkir Mahmûd. İbn Hacer el-Askalânî, Musannefâtuhu ve dirâsetu fî menhecihi ve mevâridihî fỉ Kitâbi'l-İsâbe. 2 Cilt. Beyrut: Müessesetü'r-Risâle, 1997.

Ahmed, Kadiruddin. İslâm Dinamizmi ve Entelektüel Atalet. çev. Ertuğrul Aytekin. İstanbul: İlke Yayınları, 1992.

Arslan, Ali. "Mukaddimetü İbni’s-Salah İsimli Eser Üzerine Yapılan Çalışmalar”. İnsan ve Toplum Bilimleri Araştırma Dergisi 6/5, (2017), 2459-2474.

Ayaz, Fatih Yahya. Memlükler (1250-1517). İstanbul: İsam Yayınları, 2015.

Aynî, Bedrüddîn Mahmûd b. Ahmed b. Mûsâ b. Ahmed el-. el-Alemu'l-heyyib fí şerhi Kelimi 't-tayyib. thk. Hâlid İbrâhim el-Mısrî. Riyad: Mektebetü’r-Rüşd, 1998.

Ayvall1, Ramazan. "Esbâbü Vürûdi'1-Hadîs”. Türkiye Diyanet Vakfi İslâm Ansiklopedisi. 11/362-363. İstanbul: TDV Yayınları, 1995.

Bedir, Murteza. "Mütekaddimîn ve Müteahhirîn". Türkiye Diyanet Vakfi İslâm Ansiklopedisi. 32/186-188. Ankara: TDV Yayınları, 2004.

Brockelmann, Carl. İslâm Milletleri ve Devletleri Tarihi. çev. Neşet Çağatay. Ankara: Ankara Üniversitesi İlahiyat Fakültesi Yayınları, 1964.

Çakan, İsmail Lütfi. Hadis Edebiyatı Çeşitleri, Özellikleri, Faydalanma Usulleri. İstanbul: Marmara Üniversitesi İlahiyat Fakültesi Yayınları, 1985.

Çetin, Osman. "Horasan”. Türkiye Diyanet Vakfi İslâm Ansiklopedisi. 18/234-241. İstanbul: TDV Yayınları, 1998.

Ebû Zehv, Muhammed. el-Hadîs ve 'l-muhaddisûn ev inâyetü'l-ummeti'l-İslâmiyye bi's-sünneti'n-nebeviyye. Riyad: er-Riâsetü'l-Âmmetu li-İdâreti'l-Buhûsi'l-İlmiyye ve'l-İftâi ve'd-Da'veti ve'l-İrşâd, 1984.

Emiroğlu, Nagihan. "Memlüklerde Hadis ve Ulema”. İslam Tetkikleri Dergisi 10/1 (2020), 365-387.

Emiroğlu, Nagihan. Türk (Bahri) Memlükler Döneminde Hadis İlmi. Adana: Çukurova Üniversitesi Sosyal Bilimler Enstitüsü, Doktora Tezi, 2019.

Eşer, Ahmet. Hadis İlminde Fehrese Literatürü. İstanbul: İstanbul Üniversitesi Sosyal Bilimler Enstitüsü, Doktora Tezi, 2021.

Goldziher, Ignaz. Klasik Arap Literatürü. çev. Azmi Yüksel - Rahmi Er. Ankara: İmaj Yayıncılık, 1993.

Gökçe, Ferhat. “Ali b. Osman el-Ûş̂̂’nin Yaşadığı Dönemde Hadis İlmi”. Uluslararası Ali b. Osman el-Ûş̂̂ Seтроzуити Bildirileri. ed. Ferhat Gökçe. 459-490. Bişkek: Oş İlahiyat Fakültesi Yayınları, 2018.

Gökçe, Ferhat. “Türkiye'de Memlükler Dönemi Hadis Çalışmaları”. Türkiye Araştırmaları Literatür Dergisi 11/21 (2013), 41-88.

Görmez, Mehmet. "Fıkhü'l-Hadîs". Türkiye Diyanet Vakfi İslâm Ansiklopedisi. 12/547-549. İstanbul: TDV Yayınları, 2006.

Görmez, Mehmet. Sünnet ve Hadisin Anlaşılması ve Yorumlanmasında Metodoloji Sorunu. Ankara: TDV Yayınları, 1997.

Hatiboğlu, İbrahim. "Mesâbîhu's-Sünne”. Türkiye Diyanet Vakfi İslâm Ansiklopedisi. 29/258-260. Ankara: TDV Yayınları, 2004.

İbnü’s-Salâh, Takıyyüddin. Mukaddimetu İbni ’s-Salâh. thk. Nureddin Itr. Dımaşk: Dârü'l-fikr, 1986.

İzmirli İsmail Hakkı. Hadis Tarihi. nşr. İbrahim Hatiboğlu. İstanbul: Dârulhadis, 2002.

Kallek, Cengiz. “İbn Receb”. Türkiye Diyanet Vakfi İslâm Ansiklopedisi. 20/243-247. İstanbul: TDV Yayınları, 1999. 
Kandemir, M. Yaşar. "el-Câmiu's-Sahîh”. Türkiye Diyanet Vakfi İslâm Ansiklopedisi. 7/114-123. İstanbul: TDV Yayınları, 1993.

Kandemir, M. Yaşar. "Fehrese". Türkiye Diyanet Vakfi İslâm Ansiklopedisi. 12/297-299. İstanbul: TDV Yayınları, 1995.

Kandemir, M. Yaşar. “İbn Hacer el-Askalânî”. Türkiye Diyanet Vakfi İslâm Ansiklopedisi. 19/514-531. İstanbul: TDV Yayınları, 1999.

Kandemir, M. Yaşar. "Kütüb-i Sitte”. Türkiye Diyanet Vakfi İslâm Ansiklopedisi. 27/6-8. Ankara: TDV Yayınlar1, 2003.

Kandemir, M. Yaşar. “Mukaddimetü İbni’s-Salâh”. Türkiye Diyanet Vakfi İslâm Ansiklopedisi. 31/121-124. İstanbul: TDV Yayınları, 2000.

Kandemir, M. Yaşar. “Münzirî”. Türkiye Diyanet Vakfi İslâm Ansiklopedisi. 32/35-37. İstanbul: TDV Yayınları, 2006.

Kandemir, M. Yaşar. “el-Mevzûât”. Türkiye Diyanet Vakfi İslâm Ansiklopedisi. 29/497-498. Ankara: TDV Yayınları, 2004.

Karahan, Abdullah. Hadis Edebiyatında Zevâid Kitapları. İstanbul: Sır Yayınları, 2005.

Kettânî, Muhammed b. Ca'fer el-. er-Risâletü’l-müstatrafe li beyâni meşhûri kütübi s-sünneti'l-müşerrefe. thk. Muhammed el-Muntasır b. Muhammed ez-Zemzemî b. Muhammed b. Ca'fer el-Kettânî. Dârü’lBeşâiri'l-İslâmiyye, 2000.

Köktaş, Yavuz. Fethu'l-Bârî ve Umdetu'l-Kârî'nin Metin Tahlili Açısından İncelenmesi. İstanbul: İsam Yayınları, 2009.

Köktaş, Yavuz. Hadis Fetvaları Literatürü, Özellikleri ve Örnekleri. İstanbul: Rağbet Yayınları, 2017.

Köycü, Erdoğan, el-Mizzî’nin Hadis İlmindeki Yeri, Ankara: Araştırma Yayınları, 2013.

Makdisî, Muhammed b. Tâhir el-. Şurûtu'l-eimmeti s-sitte, Beyrut: Dâru'l-Kutubi'l-İlmiyye, 1984.

Miquel, Andre. İslâm ve Medeniyeti: Doğuştan Günümüze. çev. Ahmet Fidan - Hasan Menteş. Ankara: Birleşik Dağıtım Kitabevi, 1991.

Nuaymî, Abdulkâdir b. Muhammed ed-Dımaşkî en-. ed-Dâris fì târîhi'l-medâris. Lübnan: Dârü'l-kütübi'lilmiyye, 1990.

Özafşar, Mehmet Emin. Hadis ve Kültür Yazıları. Ankara: Kitabiyat Yayınları, 2005.

Özafşar, Mehmet Emin. "Hadis İlminde Alan Evrilmesi”. İslâmiyât 6/4 (2003), 105-120.

Özkan, Halit. Memlüklerin Son Asrında Hadis. İstanbul: Klasik Yayınları, 2012.

Özkan, Halit. "Süyût̂̂”. Türkiye Diyanet Vakfi İslâm Ansiklopedisi. 38/188-198. İstanbul: TDV Yayınları, 2010.

Özkan, Halit, "Muvatta Üzerine Yazılmış Şerhler”. Hadis Şerh Literatürü ed. Mustafa Macit Karagözoğlu. İstanbul: İFAV, 2020.

Sakallı, Talat. Aynî ve Hadis Yorum/Şerh Yöntemi. Ankara: Nobel Akademik Yayıncılık, 2013.

Sehâvî, Şemsüddîn Muhammed b. Abdirrahmân. el-Cevâhir ve'd-dürer fì tercemeti Şeyhi'l-İslâm İbn Hacer. thk. İbrâhîm Bâcis Abdülmecîd. 3 Cilt. Beyrut: Dâru İbn Hazm, 1999.

Toprak, Mehmet Sait. Hadiste Derlemecilik Devrinin Başlaması ve Ûş̂̀’nin Nisâbü'l-Ahbâr'ı. İzmir: Dokuz Eylül Üniversitesi, Sosyal Bilimler Enstitüsü, Doktora Tezi, 2005.

Türcan, Zîşan. Hadis Şerh Geleneği. Ankara: Türkiye Diyanet Vakfı Yayınları, 2011.

Uğur, Mücteba. Hadis İlimleri Edebiyatı. Ankara: TDV Yayınları, 1996. 
Yardım, Ali. Hadis I-II. İstanbul: Damla Yayınları, 2012.

Yeşil, Mahmut. Hadis Bibliyografyast ve Gelişsimi (H. 700-1100/M. 1300-1688). Konya: Selçuk Üniversitesi Sosyal Bilimler Enstitüsü, Yüksek Lisans Tezi, 1989.

Yiğit, İsmail. “Ayni’yi Yetiştiren Memlükler Dönemi İlmi Hareketine Genel Bir Bakış”. Marmara Üniversitesi Ilahiyat Fakültesi Dergisi 11-12 (1993-94), 27-45.

Yiğit, İsmail. "Memlükler”. Türkiye Diyanet Vakfi İslâm Ansiklopedisi. 29/90-97. Ankara: TDV Yayınları, 2004.

Yiğit,” İsmail. Memlükler”. Türkiye Diyanet Vakfi İslâm Ansiklopedisi. Erişim 03.08.2021.

https://islamansiklopedisi.org.tr/memlukler

Yiğit, İsmail. Siyasi Dini Kültürel Sosyal İslâm Tarihi: Memlükler. İstanbul: Kayıhan Yayınları, 1991.

Yücel, Ahmet. Hadis Tarihi. İstanbul: Marmara Üniversitesi İlahiyat Fakültesi Vakfı Yayınları, 2014. 
